\title{
Natural Attributes and Agricultural Implications of Somatic Genome Variation
}

\author{
Xiu-Qing Li \\ Fredericton Research and Development Centre, Agriculture \\ and Agri-Food Canada, 850 Lincoln Road, Fredericton, \\ New Brunswick, E3B $4 Z 7$ Canada. \\ Xiu-Qing.Li@Canada.Ca; lixiuqing2008@gmail.com
}

DOI: http://dx.doi.org/10.21775/cimb.020.029

\begin{abstract}
This article proposes the concept of genome network, describes different variations of the somatic genome network, and reviews the agricultural implications of such variations. All genetic materials in a cell constitute the genome network of the cell and can jointly influence the cell's function and fate. The somatic genome of a plant is the genome network of cells in somatic tissues and of nonreproductive cells in pollen and ovules. Somatic genome variation (SGV, approximately equivalent to somagenetic variation) occurs at multiple levels, including stoichiometric, ploidy, and sequence variations. For a multicellular organism, the term "somatic genome variation" covers both the variation in part of the organism and the generation of new genotype individuals through somatic means from a sexually produced original genotype. For unicellular organisms, genome variation in somatic nuclei occurs at the whole organism level because there is only a single cell per individual. Growth, development and evolution of living organisms require both stability and instability of their genomes. Somatic genome variation displays many more attributes than genetic mutation and has strong implications for agriculture.
\end{abstract}

\section{Introduction}

Meiotic chromosome recombination and segregation during the sexual reproduction cycle are known to constitute an important approach for plants to increase genetic variation and facilitate adaptation (Bai, 2015). It is also known that somatic mutation sometimes causes disease in humans (Watson et al., 2013). However, much less is known about how variation of the somatic genome affects the growth and performance of organisms in agriculture. Plants derived from vegetative (somatic) propagation are often assumed to be identical in their genome (unless gene mutation occurs), regardless of which explants and propagation methods were used and whether the crop is sexually reproduced or vegetatively propagated. In reality, plants derived from different propagation methods often perform differently in terms of growth (which is often assumed to be physiological or epigenetic) and are sometimes found to be different in terms of their rate and extent of mutation (Li et al., 1985). Genetic and genomic research has discovered that plant genomes have both developmental and environmental variations that have implications for plant performance and propagationassociated outcomes. The variation of the somatic genome in nature is the scientific basis for most somatic breeding technologies, including Agrobacterium-mediated genetic transformation, tissue-culture-induced variation, graftinduced genetic variation, and cell fusion, even though the frequency of variation is artificially enhanced and the outcome is artificially engineered. This article proposes the concept of genome network, describes somatic genome variation (SGV) at different levels, reviews the implications of SGV for agriculture, and suggests how SGV can be used or minimized in agriculture.

Genome network, somatic genome, and somatic genome network

Traditionally, the term "genome" usually means the sum total of the nuclear chromosomes. However, in the reality of biology, all the genetic materials in a cell constitute the "genome network" (or genome system) of the cell and jointly determine the phenotype of the cell. Certain algae such as the chlorarachniophyte Bigelowiella natans also have an endosymbiont that has a chloroplast and a remnant eukaryotic endosymbiont nucleus (nucleomorph) (Curtis et al., 2012). Therefore, the genome network of a Bigelowiella natans cell has a nuclear genome, a nucleomorph genome, a chloroplast genome, and one or two mitochondrial genomes. In this article, we discuss the genome network in its narrow definition and exclude temporary genetic materials, such as parasite viruses and endophytes, in the cell.

The term "somatic genome" in this article usually refers to the "somatic genome network", which includes the sum total of the nuclear chromosomes, plastid genome, mitochondrial genome, extrachromosomal DNA, and mitochondrial plasmids. Similar to ciliates, which have a germline nucleus and a somatic nucleus in the same cell, a pollen grain has a vegetative cell and one or two generative cells. The vegetative nucleus and the organelles in the pollen cytoplasm (a part of the vegetative cell, because the generative cells are usually small and enveloped) can likely be viewed as a cell. The genome network (the vegetative nucleus and the cell's organelles) should be classified as a part of the somatic genome. Therefore, the term "somatic genome" can be applied to both the genome in cells of the somatic tissues and the genome in nonreproductive cells of ovules and pollen. The term "somatic genome" is different from "pan-genome," which describes the full complement of genes in the nuclear genome of a clade and is usually used to compare gene contents or fragment deletions and additions among closely related strains (Medini et al., 2005). 


\section{Somatic genome variation, somagenetic variation, and somaclonal variation}

Somatic genome variation (SGV) refers to variation of the somatic genome, which includes the genome network in somatic cells and the somatic nuclei (such as in pollen) and cytoplasmic genomes in reproductive cells. The term "somatic genome variation" is equivalent to the term "somagenetic variation" when it is being applied to the somatic genome. The term "somagenetic variation" was initially coined for "changes of DNA sequence in somatic cells" ( $\mathrm{Li}, 2008,2009)$ but has been expanded to include both SGV and some non-Mendelian genetic variations of the germline genome, such as extrachromosomal DNA, organelle genome variation, and telomere length changes unrelated to meiotic recombination $(\mathrm{Li}, 2016)$. Therefore, somagenetic variation includes all genetic variations except those generated by meiotic recombination and segregation (Mendelian genetic variations). "Somatic genome variation" emphasizes the genomic aspect more, whereas "somagenetic variation" emphasizes the genetic aspect more and is more parallel to the terms "epigenetic variation" (DNA methylation and gene expression activity changes) and "Mendelian genetic variation." The term "somatic genome variation" is also different from "somaclonal variation," because the latter was coined to describe the variations (genetic and nongenetic) that are detected in in vitro-cultured cells and their regenerated plants (Larkin and Scowcroft, 1981). Therefore, some somaclonal variations are SGVs and some are not.

\section{Natural attributes of somatic genome variation}

For the cellular genome network, there are many categories of SGV, including not only gene mutations and primary sequence changes but also the ploidy of each member of the genome network and the relative ratios among the members of the genome network. When some cells double their ploidy or get eliminated, the genome population of the organism changes. All SGVs are changes at the genetic material level (either sequences of the genome or DNA quantity in the cell) and usually play roles in the growth and development of the cell and the organism. Most SGVs are programmed, systemic, and dynamic during growth and development or in response to the environment. The nature of most SGVs is very different from that of the classical concept of the mutation of Mendelian genes. Many physiological, developmental, or gene-expression changes in plants actually also involve somagenetic variations of the genome network. The major categories of SGV are listed in Table 1 and discussed in the Implications of Somatic Genome Variation for Agriculture section below. This list of SGV categories in agricultural organisms emphasizes plants but also touches on agricultural animals and microorganisms to a certain degree.

Which variations should be classified as SGV? For singlecelled microorganisms such as yeasts and some algae, any genetic variation during the somatic stage should be classified as SGV. Genomic variation in certain somatic parts of a plant obviously fits the definition of SGV. Should whole-plant ploidy differences between clonal plants be classified as SGV? Yes, they should, if a plant with a new genotype (a new ploidy level or a mutated genomic sequence) is generated from a meristematic somatic cell, because new genotypes can be viewed as variations from the original sexually reproduced genotype.

Some transformation occurs naturally and results in somaclones or cultivars carrying natural genetic modifications, such as in the case of sweet potato (Ipomoea batatas) (Kyndt et al., 2015). Therefore, genetic transformation is a type of SGV, at least in certain cases. This type of SGV is not a developmental and internally driven variation but rather is induced by external biotic or abiotic factors. It is clearly not appropriate to exclude variation caused by genetic transformation from SGV; therefore, the present article discusses SGV is in its broad sense-including SGV that occurs either in part of the organism or in organisms sprouted or regenerated from mutated somatic cells.

\section{Implications of somatic genome variation for agriculture}

Somatic genome variation has implications for many aspects of agriculture, even though sometimes people use SGV unintentionally in agriculture. The following are some examples of these agricultural implications (Table 1), but they by no means constitute a complete list.

\section{Cellular-level variation}

Programmed cell death and DNA degradation. Xylem formation in the vascular tissues requires programmed cell death, including DNA fragmentation in the cell (Bollhöner et al., 2012). Xylem is essential for the growth of higher plants. Programmed cell death, including apoptosis and autophagy, removes damaged or infected cells and therefore can minimize the spread of environmental stresses and pathogen attacks to other cells (Ma and Berkowitz, 2011; Vasil'Ev et al., 2011; Wang et al., 2013). The activation of DNA damage responses is an intrinsic component of plant immune responses (Yan et al., 2013). Interestingly, fascinating analogies have been made for the caspase and caspase-like networks between animal innate immune responses and plant hypersensitive responses (Coll et al., 2011). Bacteria-induced programmed cell death involves proteasome-dependent tonoplast and plasma membrane fusion, after which vacuolar antimicrobial and death-inducing contents are discharged into the apoplast (Pajerowska-Mukhtar and Dong, 2009). Programmed cell death is also nearly essential for plant morphology such as leaf shape formation (Gunawardena et al., 2004). It is unclear whether somatic genome degradation also occurs in a programmed way during the programmed cell death responsible for morphological development. At the least, DNA-damage-induced programmed cell death is a method of somatic-cell cleaning, including removal of the somatic genome that is either too damaged to be repaired or can no longer be kept in the tissue.

Cell fusion, somatic hybrids, cytoplasmic hybrids (cybrids), and transferred nuclei. Cell fusion occurring in vivo has been reported in yeast (Salzman et al., 2015), plants (Maruyama et al., 2015), and animals (Zhou and Platt, 2011; Pérez-Vargas et al., 2014). Cell fusion occurs 
Table 1. Natural attributes of somatic genome variation

\begin{tabular}{|c|c|}
\hline Type of Variation & Category and Natural Attributes \\
\hline \multirow[t]{3}{*}{ Cellular-level variation } & Programmed cell death and DNA degradation (e.g., xylem cell DNA fragmentation) \\
\hline & 2. Cell fusion, somatic hybrids, cytoplasmic hybrids (cybrids), and transferred nuclei \\
\hline & 3. Graft hybrids and intercellular genome trafficking of organelle or nuclear materials \\
\hline \multirow{5}{*}{$\begin{array}{l}\text { Ploidy and chromosome number } \\
\text { variation-resulted whole } \\
\text { organisms }\end{array}$} & 4. Somatic-cell-derived organisms of new ploidy levels \\
\hline & 5. $\quad$ Doubled haploids in the whole organism \\
\hline & 6. B chromosome number variation \\
\hline & 7. Extrachromosomal circular DNA molecules \\
\hline & 8. Chromosome elimination and instability in interspecific hybrids \\
\hline \multirow[t]{3}{*}{ Endoploidy variation } & 9. Endoploidy with chromosome number variation \\
\hline & 10. Endopolyploidy and formation of multiple chromatid chromosomes in somatic cells \\
\hline & 11. Endoreplication variation between tissues caused by differences in the cell cycle phase \\
\hline \multirow{8}{*}{$\begin{array}{l}\text { Intra- and interchromosomal } \\
\text { variation }\end{array}$} & 12. Telomere sequence length variation \\
\hline & 13. Repetitive sequence variation \\
\hline & 14. Chromosomal structure changes, e.g., transposition \\
\hline & 15. DNA copy number variation \\
\hline & 16. Homologous recombination and the evolution of gene direction \\
\hline & 17. Somatic crossover \\
\hline & 18. Somatic gene conversion \\
\hline & 19. DNA transposition in somatic cells \\
\hline $\begin{array}{l}\text { Dedifferentiation- and } \\
\text { redifferentiation-induced } \\
\text { variation and new clonal } \\
\text { genotypes }\end{array}$ & 20. Natural clonal variation and in vitro somaclonal variation at the genome network level \\
\hline \multirow[t]{3}{*}{ DNA damage and gene mutation } & DNA damage that may or may not cause mutations \\
\hline & $\begin{array}{l}\text { 22. Somatic cell mutation (e.g., bud mutant on a plant, driven by endogenous and exogenous } \\
\text { factors) }\end{array}$ \\
\hline & 23. Environmentally induced DNA insertion or deletion \\
\hline \multirow{4}{*}{$\begin{array}{l}\text { Plastid genome sequence or } \\
\text { DNA amount variation }\end{array}$} & 24. Plastid ploidy variation among plastids \\
\hline & 25. Plastid DNA amount per cell \\
\hline & 26. Chloroplast heteroplasmy in a cell \\
\hline & 27. Chloroplast mutation \\
\hline \multirow{5}{*}{$\begin{array}{l}\text { Mitochondrial genome sequence } \\
\text { or DNA amount variation }\end{array}$} & 28. Variation in mitochondrial DNA amount per cell or the ratio of mitochondrial to nuclear DNA \\
\hline & 29. Stoichiometric variation of the ratio between mitochondrial subgenome molecules \\
\hline & 30. Homologous recombination of mitochondrial DNA \\
\hline & 31. Mitochondrial gene mutation and inheritable DNA rearrangements \\
\hline & 32. $\quad$ Mitochondrial plasmids \\
\hline \multirow{5}{*}{$\begin{array}{l}\text { DNA transfer, organelle } \\
\text { transmission, and organelle } \\
\text { genome segregation }\end{array}$} & 33. Horizontal transfer of DNA, e.g., between hosts and parasites \\
\hline & 34. Genetic transformation of the nuclear or chloroplast genome \\
\hline & 35. Maternal transmission and occasional paternal transmission of plastids and mitochondria \\
\hline & Chloroplast genome segregation in somatic hybrids from protoplast fusion \\
\hline & $\begin{array}{l}\text { 37. Genetic material exchanges between hosts and stable or temporary endosymbionts } \\
\text { (viruses, endobacteria, or endofungi) }\end{array}$ \\
\hline \multirow[t]{2}{*}{ Intercompartmental variation } & 38. Intercompartmental interaction at the genome level \\
\hline & 39. Intercompartmental exchanges of genetic materials \\
\hline
\end{tabular}


between the persistent synergid cell and the endosperm in Arabidopsis thaliana (Maruyama et al., 2015). Somatic hybrids from protoplast fusion have mitochondrial genome segregation and generate new mitochondrial genomes carrying mitochondrial DNA (mtDNA) from both parents (Belliard et al., 1979). In intergeneric somatic hybrids of Valencia orange (Citrus sinensis), the mtDNA pattern was correlated with phenotypic abnormality, but a more complex mtDNA banding pattern coincided with increased plant vigor (Cheng et al., 2003).

Graft hybrids and intercellular genome trafficking of organelle or nuclear materials. In grafts, intercellular trafficking of organelle or genetic materials occurs between neighboring cells (Stegemann and Bock, 2009; Liu et al., 2010; Thyssen et al., 2012). Not only can grafting influence epigenetic factors such as DNA methylation and gene silencing (Crété et al., 2001; Yang et al., 2015), but the transfer of an entire nuclear genome and the formation of allopolyploid hybrids was recently reported in grafting between tobacco (Nicotiana) species followed by tissue culture and plant regeneration (Fuentes et al., 2014). Another study detected in grafted plants the cell-to-cell movement of the entire $161 \mathrm{~kb}$ plastid genome, most likely in intact plastids, but the related mitochondria were not transferred (Thyssen et al., 2012). The fact that researchers obtained some pupil plants (scions) that acquired some hereditary characteristics from the mentor variety may suggest that some DNA circulates from mentors to scions (Anker and Stroun, 2012) although the carrier for the DNA is not known. The screening of seeds collected from green-leaved plum (Prunus ceraifera cultivar Pissardii) trees (as crown) that were grafted with purpleleaved plum (Prunus salicina) (as scions) found that $2.3 \%$ to $15.8 \%$ of the seedlings had purple leaves, a result that suggested that they were graft hybrids (Zhou et al., 2013). Although that report is very interesting, more research confirmation at the genomic level is needed to determine whether the seedlings were nuclear hybrids or cybrids, whether the variation was genetic or epigenetic, and whether there was any contamination from pollen traveling through the air from far away, given that trees are tall and difficult to cover fully to prevent such contamination.

\section{Ploidy and chromosome number variation-resulted whole organisms}

Somatic-cell-derived organisms of new ploidy levels. Whole-plant polyploidy or triploidy can result from sexual reproduction such as a cross between a tetraploid and a diploid, which is obviously not a question of SGV. However, polyploidy or other types of ploidy variation such as aneuploidy can sometimes originate somatically. For example, chromosome doubling, with or without artificial treatment with colchicine (a mitosis-inhibiting chemical), at an early stage of seedling or plantlet growth can cause the shoot meristem to become polyploid; after the death of the nonpolyploid original tissues or after cutting, the whole plant or nearly the whole plant becomes polyploid. In Bryophyllum species, primordia are generated somatically on leaf fringes (Slabý et al., 1990), and many primordia developed into plantlets and eventually drop off and grow into plants; the whole plantlet will have the new ploidy level if the plantlet is from a meristematic cell that has ploidy variation such as polyploidy or aneuploidy.

Chromosome doubling and ploidy increase are widely used for improving crop yield. The treatment of plant roots and shoots with colchicine often leads to chromosome doubling and polyploid production. Chromosome-doubling-produced tetraploid lines $(2 n=4 x=32)$ from diploid alfalfa $(2 n=2 x=$ 16) showed yield increases ranging from $12 \%$ to $32 \%$ (McCoy and Rowe, 1986). Chromosome doubling and ploidy variation likely provide a new type of variation in gene expression, because of epigenetic interactions between redundant genes (Comai, 2005). At least in cotton (Gossypium) allopolyploid lines, domestication may increase expression bias in fibers toward the $D$ genome, which suggests that D-genome recruitment under human selection during domestication is involved (Hovav et al., 2008).

Doubled haploids in the whole organism. Doubled haploids are widely used as parental lines in crosses to produce hybrids in breeding programs that are based on hybrid vigor. This approach is sometimes called "haploid breeding" (Hanifi-Mekliche and Gallais, 1999) and is frequently used in commercial seed production, as in the case of maize (Zea mays) (Gordillo and Geiger, 2008; Smith et al., 2008; Wegenast et al., 2008; Geiger and Gordillo, 2009), or in the creation of homozygous lines for genetic studies such as gene mapping and cloning (Formanova et al., 2006). Cultivated potatoes (Solanum tuberosum) are mainly tetraploid, and diploid lines are viewed as haploid, in comparison with the tetraploid lines. The ploidy of diploid plants can be doubled to become tetraploid before the plants are used as parents in tetraploid potato breeding. The use of homozygous doubled-haploid plants has greatly facilitated genome sequencing projects such as the one for potato (Xu et al., 2011).

$B$ chromosome number variation. Many plants have $B$ chromosomes, and the dynamics of $B$ chromosomes in the population depends on their non-Mendelian transmission (Puertas, 2002). It is known that $B$ chromosomes exist mainly in large-sized nuclear genomes in flowering plants (Trivers et al., 2004). The number of $B$ chromosomes has wide range of intratissue variation, even though mitosis is apparently normal when there are B chromosomes, such as in Ranunculus bulbosus plants (Bianchi et al., 1997) and maize (Ma and Li, 2015).

Extrachromosomal circular DNA molecules. Extrachromosomal circular DNA molecules, including those derived from satellite repeats, that occur in plants can be detected by electron microscopy (Navrátilová et al., 2008) and identified from the nuclear DNA fraction (Kinoshita et al., 1985). Extrachromosomal circular DNA, including $5 S$ ribosomal DNA and some noncoding repeats, can be detected in Arabidopsis thaliana and Brachycome dichromosomatica using two-dimensional gel electrophoresis (Cohen et al., 2008). Further research is required to determine whether the extrachromosomal 
circular DNA molecules are created during meiosis, mitosis, or in interdivision time, and whether these DNA molecules are dynamic in quantity during plant growth and development.

Chromosome elimination and instability in interspecific hybrids. Interspecific hybrids often have chromosome instability, chromosome elimination, and aneuploid formation, as is the case with barley (Hordeum vulgare) (Linde-Laursen and von Bothmer, 1988). Sometimes haploids are produced when only hybrids are expected (Bennett et al., 1976; Bordes et al., 1997), which suggests that a parental set of chromosomes is eliminated from the zygote somatically during the early stage of embryo development. In hybrids of Hordeum vulgare $\times$ Hordeum bulbosum, the Hordeum bulbosum chromosomes were eliminated. The maximum rate of chromosome elimination in each tissue was reached when that tissue first synthesized significant amounts of new cytoplasm (second day after pollination in the endosperm and third day in the embryo) (Bennett et al., 1976). Chromosome elimination occurs in other plants as well, including Triticeae, oat (Avena sativa), and pearl millet (Pennisetum glaucum) (Ishii et al., 2010). In maize, after pollination with a haploid inducer, up to $10 \%$ of the seeds can be doubled haploids (Melchinger et al., 2013). Potato haploids can be obtained by pollinating tetraploid potato cultivars (Solanum tuberosum) with pollen from a haploid inducer, which is usually a line of Solanum phureja (Liu and Douches, 1993). An analysis of induced potato haploids with DNA markers suggested that it was the inducer chromosomes that were eliminated and that the Solanum tuberosum chromosomes remained, which is a situation similar to parthenogenetic offspring from unfertilized eggs (Samitsu and Hosaka, 2002). The production of potato haploids through haploid inducers has been used in potato breeding and genetic mapping research (Hosaka, 1999). A monoploid potato line (Paz and Veilleux, 1999) greatly helped advance potato genome sequencing (Xu et al., 2011). The DNA elimination in hybrids does not always occur rapidly following the division of zygotes. In allohexaploid plants of Triticum turgidum $\times$ Aegilops tauschii, the elimination of two alleles of Aegilops tauschii DNA sequences does not occur in germ cells but instead occurs during embryo development in the second, third and fourth sexual generations, likely in a tissue-specific manner (Khasdan et al., 2010).

\section{Endoploidy variation}

Endoploidy with chromosome number variation. Root tips are found to have high frequency of aneuploidy variation in Piper magnificum (Nair, 2007), even though the mechanisms of the detected variation is still unclear. Diploid maize seedlings can have some tetraploid or aneuploidy cells in leaves and root even though the frequency is very low (Ma and Li, 2015).

Endopolyploidy and formation of multiple chromatid chromosomes in somatic cells. In an analysis of the endopolyploidization of several organs of 54 seed-plant species belonging to two gymnosperm families and 14 angiosperm families, phylogenetic position, life cycle, genome size, and organ type were found to have effects on endopolyploidization (Barow and Meister, 2003). Polytene chromosomes were found in anther tapetal cells of cowpea (Vigna unguiculata) and embryo suspensor cells of runner bean (Phaseolus coccineus) using fluorescent in situ hybridization (Guerra, 2001). Polytene chromosomes were detected in secretory cells from the larvae of the biting midge insect Forcipomyia nigra (Urbanek et al., 2013).

Endoreplication variation between tissues caused by differences in the cell cycle phase. The balance between different stages of cell cycle is regulated sensitively, and several genes and pathways, such as the ubiquitinSCFSKP2A pathway in Arabidopsis (Del Pozo et al., 2006), are involved in this regulation. One of the variants of cell cycle is "endocycle", in which chromosomes are not separated but genomic DNA is successively duplicated. The percentage of root cells arrested in G2 in 3-day-old seedlings of Pisum sutivum was higher than that in 10-dayold seedlings (Evans et al., 1987). The percentage difference of each cell cycle phase between tissues (Evans et al., 1987; Kotogány et al., 2010) suggests that each type of tissue has its own appropriate percentage of the cell phase for plant growth and development.

\section{Intra- and interchromosomal variation}

Telomere sequence length variation. Telomere sequence length in plants varies seasonally in the fruit tree Ginkgo biloba (Song et al., 2010). Telomeres are involved in the life and death of maize seeds (Osborne and Boubriak, 2002). It is also known that telomeres shorten during differentiation and grow in callus culture in barley (Kilian et al., 1995), suggesting that telomere variation is dynamic during barley growth and development. The regulation of telomere length can be a potential approach to improve crop performance when an effective method is available.

Repetitive sequence variation. In plants, the intergenic spacer region is among the most variable repetitive sequences between closely related plant lines, even among somatic cells (Rogers and Bendich, 1987). In situ hybridization revealed variation of ribosomal DNA locus locations among cells of the same onion (Allium) plant (Schubert and Wobus, 1985). The DNA reassociates increase significantly from the gastrula stages to the early neurula stage during early embryonic differentiation in the newt Triturus vulgaris, suggesting variation in repetitive DNA (Schubert and Lohmann, 1982). Ribosomal DNA rearrangements occur in late-generation telomerasedeficient cells in Arabidopsis (Siroky et al., 2003). Repetitive sequence amounts after the in vitro culture of pea (Pisum sativum) apices were found to vary, as measured using cytophotometry and slot blot analyses (Cavallini et al., 1996). Repetitive DNA in the nuclear DNA content varies widely among and within species and influences phenotypic differences between species (Meagher and Vassiliadis, 2005). Variants in short tandem repeats require genotyping with targeted assays and genotype-phenotype association analysis with appropriate statistical methods (Press et al., 2014). The present author used multiple laboratory techniques (Illumina sequencing, NanoString hybridization, and two quantitative polymerase chain reaction methods) to analyze the DNA of potato and 
maize plants and detected dynamic variation in repetitive DNA between leaf and root tissues (unpublished). Therefore, repetitive DNA in the somatic genome is likely involved in plant performance. Contrary to the repetitive sequence regions, the distance between the polyadenylation signal motifs and the mRNA polyadenylation sites is highly conserved between dicotyledonous plants and monocotyledonous plants and between mammals and nonmammal animals, suggesting that different regions of the chromosome have different degree of stability ( $\mathrm{Li}$ and $\mathrm{Du}$, 2014a). Clearly different regions of the chromosome have different degrees of instability.

Chromosomal structure changes. Chromosomal structure rearrangement, including the addition or deletion of a large fragment such as a chromosome arm, occurs in certain somatic cells. The translocation of chromosomes occurs in many plants, such as cotton (Gossypium hirsutum) (Sanam'yan and Musaev, 1990). Some terminal chromatid deletions apparently trigger unscheduled apoptosis, which is likely a rescue approach for the plant, but extensive cell death in meristems eventually causes reduced growth (Schubert et al., 1998). Chromosomal rearrangements often change growth characteristics.

DNA copy number variation. DNA copy number variation is common in plants, such as alfalfa (Medicago sativa), according to Southern and slot blot hybridization (Kidwell and Osborn, 1993). Copy number variation differences have been found between normal and tumor tissues in dogs (Canis lupus familiaris) and between twins in humans (Bruder et al., 2008). In plants, ribosomal RNA genes (ribosomal DNA) are highly variable in terms of copy number and intergenic spacer length between lines within species and likely also among somatic cells of individual plants (Rogers and Bendich, 1987).

Homologous recombination and the evolution of gene direction. Homologous recombination in somatic cells is often related to sister chromosome alignment, which occurs usually at the centromeres, in some ribosomal DNA, and at a few other high-copy loci (Schubert et al., 2007). In zebrafish (Danio rerio), DNA damage during the G0/G1 phase of cell division can trigger an RNA-templated homologous recombination to counter the damage and to protect genome stability, and the process requires Cockayne syndrome protein B (Wei et al., 2015).

Recombination of invert repeats can change the directional order of genes. The direction of genes on the chromosome is characteristic for different kingdoms and different groups of species and shows a clear evolutionary tendency from being arranged in the same direction to being arranged oppositely during the evolution from prokaryotes to eukaryotes ( $\mathrm{Li}$ and $\mathrm{Du}, 2012$; $\mathrm{Li}, 2015 \mathrm{a}$ ). The difference in gene direction between archaeans and bacteria demonstrates that nonsexual genome variation occurs. However, the overall high similarity of gene direction between species within the same family or kingdom suggests that the evolution of gene direction is very slow and that the genome is largely stable in terms of gene direction during the growth and development of an organism.

Somatic crossover. Both chromosome crossover and gene conversion occur in somatic cells, as well as in gametes such as in Arabidopsis thaliana (Berchowitz and Copenhaver, 2009). Somatic crossover (also known as mitotic crossover) has been detected in various studies (Roncuzzi et al., 1985; Courtial et al., 2001; Hartung et al., 2008). Irradiation with X-rays can increase the rate of somatic crossovers in tobacco (Nicotiana tabacum) (Evans and Paddock, 1977). DNA repair is likely involved in somatic recombination in maize (Pandey, 1983).

Somatic gene conversion. Somatic gene conversion between alleles of the same locus was detected in a semidominant mutation of leaf color in Nicotiana sylvestris (Li, 1987). Somatic gene conversion likely occurs during chromosome repair after sublethal irradiation of pollen in maize (Zea mays) (Pandey, 1983). Some hybrids from a cross between triploid and diploid individuals in rice (Oryza sativa) could be diploid, had high levels of homozygosity, and showed a high frequency of genome-wide gene conversion of the analyzed molecular markers (Xu et al., 2007). Gene conversion also occurs frequently in pathogens. A hybrid strain of the soybean pathogen Phytophthora sojae had a high frequency of gene conversion during vegetative growth (Chamnanpunt et al., 2001). Gene conversion plays a role in the pathogenicity of plant fungal pathogens.

DNA transposition in somatic cells. Somatic cell DNA transposition was first found in maize (McClintock, 1950), and it is now known that somatic transposition is active throughout plants and animals (Huang et al., 2012). Transposons (Mu-like elements, or MULEs), similar to the maize Mutator system, have been found to be horizontally transferred between cereals, including maize, Setaria, and rice (Diao et al., 2006). DNA transposition is likely one of the main mechanisms of gene mutation. Transpositioninduced mutation offers novel phenotypic diversity for crop improvement (Paszkowski, 2015).

\section{Dedifferentiation- and redifferentiation-induced variation and new clonal genotypes}

Natural clonal variation and in vitro somaclonal variation at the genome network level. Some ciliates selectively maintain a small portion of genes and deleted most other genes in the somatic nuclei, and the genomic rearrangement is mediated by RNA during the differentiation and development (Bracht et al., 2013; Bracht, 2016). Clonal genetic variation has been detected in microorganisms (Nakano et al., 2007), animals (Loxdale et al., 2013), and plants (Larkin and Scowcroft, 1981). Clonal cultivars are often from bud mutation in plants (Sun et al., 2007; Pan et al., 2012; James and McDougall, 2014; Reuscher et al., 2014). Various potato cultivars are selected from clonal variation; for example, 'Red Norland' and 'Dark Red Norland' are clonal variants of the cultivar 'Norland' (Waterer et al., 2011). 
The frequency and extent of clonal ploidy variation and gene mutations are greatly enhanced when cells are produced by in vitro culture. "Somaclonal variation" is a term used specifically for the variation induced by in vitro cell culture (Larkin and Scowcroft, 1981). Some somaclonal variation is at the ploidy level, some is gene mutation, and some is likely physiological or epigenetic. The variation is likely caused by the dedifferentiation and redifferentiation of cells and tissues. Aneuploid plants usually have abnormal growth. For example, in the plants regenerated from an embryogenic cell line of the allopolyploid coffee (Coffea arabica), all eight aneuploid plants that were missing one to three chromosomes were either dwarf or had abnormal leaves (Bobadilla Landey et al., 2015).

Plants with changed chromosome numbers, such as plants with aneuploidy (those in which most cells are aneuploid), were frequently detected among plants regenerated from tissue culture (Larkin and Scowcroft, 1981), raising the possibility that some cells in the tissue culture explants already had ploidy variations. Both polyploid and aneuploid cells can be found in the leaves of healthy, vigorously growing maize seedlings, even though the frequency is very low (e.g., one tetraploid in 367 leaf cells) (Ma and $\mathrm{Li}$, 2015). The detection of somatic cells with changed chromosome numbers in vigorous, healthy plants strengthens the hypothesis that ploidy variation in the source explants under culture contributes to the detected ploidy variation in cultured cells and regenerated plants. However, dedifferentiation and redifferentiation during cell culture also contribute to the detected ploidy variation, given that different culture methods often induce different frequencies of somaclonal variation. The expression activities of genes that are responsible for centromere and ploidy stability are expected to change during dedifferentiation and redifferentiation and may therefore result in chromosome number variation in some cultured cells. The epigenetic changes in gene expression may last for many mitotic generations of cell division, may even be heritable over a certain number of reproductive generations, and may consequently still cause genome instability in both generation zero and the immediately following generations of regenerated plants.

In a study using both selfing and diallel crosses to investigate the mode of inheritance of somaclonal variation in tomato (Solanum lycopersicum; synonym: Lycopersicon esculentum) and lettuce (Lactuca sativa), Demarly and Sibi (1989) detected that some new traits differed from the original line but did not have clear segregation among progeny plants within the same regenerated line and that some of these uniform variations could not be explained by cytoplasmic effects. Those authors (Demarly and Sibi, 1989) coined the term "epigenic variation" for the somaclonal variation whose inheritance is neither in Mendelian segregation nor cytoplasmic inheritance. Somaclonal variation has been used in the somatic breeding (using somaclones) of potato and various other crops. For sexually reproducing plants, somaclonal variation often lacks stability for the variant traits, as is the case for wheat (Bozorgipour and Snape, 1997), and sometimes does not have a clear increase in the mutation spectrum, as is the case for Lotus corniculatus (Damiani et al., 1990). However, in vegetatively propagated plants, some traits from somaclonal variation, such as chip color quality in potato, were found to be quite stable over at least several generations of vegetative propagation (Nassar et al., 2011).

\section{DNA damage and gene mutation}

DNA damage that may or may not cause mutations. DNA damage can affect plant growth. Plants in soil contaminated with polychlorinated biphenyls showed increased DNA damage and reduced growth and distorted leaves, even though no detectable increase in mutation frequency was found (Gichner et al., 2007). According to a comet assay of oxidative DNA damage and repair in lymphocyte cell cultures and another assay of lipid peroxides in serum, organophosphate pesticides induce oxidative DNA damage in agricultural workers (Kisby et al., 2009).

Somatic cell mutation. It is usually known that some exogenous factors such as radiation and chemical mutagens can cause DNA mutation; however, endogenous factors and processes such as transcription during gene expression and the activity of DNA deaminase (Harris, 2015) can also cause gene mutation. The reader is referred to Kim and Jinks-Robertson (2012) for the effects of transcription on genome instability. Gene mutation of topranked proteins can cause severe diseases in animals (Du et al., 2012; Li et al., 2016). In agriculture and horticulture, bud mutation in plants, has generated many new cultivars for horticultural crops or trees, including flower color and florescence mutants in chrysanthemum (Chrysanthemum morifolium) (Sun et al., 2007), chimeric chrysanthemum (Yamaguchi et al., 2009), anthocyanin color mutants in pear (Pyrus communis) (Chikwambi and Muchuweti, 2008), ever-growing mutant in peach (Prunus persica) (Jiménez et al., 2010), sweet orange (Citrus sinensis) (Pan et al., 2012), giant-fruit pear (Reuscher et al., 2014), and betterquality orange (Pan et al., 2014). DNA polymorphisms were detected among clones in natural plant populations of Rhododendron ferrugineum (Escaravage et al., 1998). Despite occasional somatic mutations in some cells, DNA fingerprinting is known to be a powerful tool in genotyping, such as in identifying potato cultivars (Li et al., 2008) and in dissecting genetic structure and diversity in agricultural trees such as farmer collections of cacao (Theobroma cacao) in the Peruvian Amazon (Zhang et al., 2011). Somatic genome variation is obviously not always an issue for cultivar identification. This is likely because most researchers will choose the reproducible molecular markers in the DNA fingerprinting analysis and also because the most dynamic regions on the genome are more difficult to assemble during the reconstruction of the reference genome and therefore are less frequently used in developing molecular markers. Many SGVs are not at the primary-sequence level and therefore may not alter the cultivar identification results, depending on the resolution levels used in the DNA genotyping techniques and the threshold for recording the markers. 
Second-generation sequencing and certain bioinformatic pipelines (Xiang and $\mathrm{Li}, 2015$ ) can allow the wholegenome-level comparison of repetitive sequence variation, and be used for single nucleotide polymorphisms (SNPs), between somatic tissues. The whole-genome-level comparison is likely sensitive to primary-sequence variation and certain types of stoichiometric variation, because the variations may cause incorrect alignment or change the SNP ratios. For this comparison, the similar shared nuclear and organellar sequences must be removed; otherwise, the dynamic variation of the chloroplast and organelle DNA content could cause artifact SNPs or repetitive DNA variations during the bioinformatic analysis of the nuclear genome. Several laboratory protocols are available for preparing nuclear DNA, chloroplast DNA, and mtDNA separately (Li, 2015b).

Environmentally induced DNA insertion or deletion. The environment can induce DNA deletion, a site-specific insertion, or rearrangement in flax (Linum usitatissimum) (Cullis, 1973; Schneeberger and Cullis, 1991; Chen et al., 2005) as well as genome instability in Arabidopsis (Boyko and Kovalchuk, 2011). It is also known that environmentally induced epigenetic changes can be transgenerational and therefore heritable to a certain degree in plants (Boyko and Kovalchuk, 2011; Suter and Widmer, 2013). However, epigenetic variation and SGV are sometimes associated; for example, UVC can induce epigenetic activation of transposons in Arabidopsis thaliana (Migicovsky and Kovalchuk, 2014), and gene transposition is obviously a type of SGV, because the genome primary sequence is changed by the deletion or insertion. This type of SGV is expected to have a high probability of transgenerational inheritance if the transposition occurs in a plant's buds or reproductive cells. Both the genome itself and its expression are involved in the plant response to the environment (Li, 2009).

\section{Plastid genome sequence or DNA amount variation}

Plastid ploidy variation among plastids. In a study of plastid DNA amounts per plastid in diploid spongy mesophyll cells of Beta vulgaris using fluorochrome DAPI (4,6-diamidino-2phenylindole) staining, the DNA amounts per plastid ranged from 0.0014 to $0.02 \mathrm{pg}$ depending on leaf development stages (Rauwolf et al., 2010). Plastid DNA synthesis is very active and builds up the plastid DNA amount at the early stage of plastid biogenesis prior to active transcription (Baumgartner et al., 1989).

Plastid DNA amount per cell. The amount of plastid DNA varies at the cellular level among tissues and among developmental stages ( $\mathrm{Ma}$ and $\mathrm{Li}, 2015$ ), suggesting that variation of the plastid DNA amount is important for plant growth and development. Despite a report of chloroplast DNA fragmentation and degeneration under light (Kumar et al., 2014), other studies found that green leaves usually have higher plastid DNA amounts in comparison with nongreen leaves or immature regions of leaves (Udy et al., 2012; Ma and $\mathrm{Li}, 2015)$. A study using [ ${ }^{3} \mathrm{H}$ ]thymidine labeling found that the chloroplasts of the algal species Ochromonas danica contain more DNA than its proplastids do (Gibbs et al., 1974). Chloroplast DNA degrades during natural senescence in maple leaves, according to DNA hybridization (Fulgosi et al., 2012).

Chloroplast heteroplasmy in a cell. A kiwifruit (Actinidia deliciosa) cultivar, 'D uno', was found to be a periclinal plastid chimera, according to data from a DNA restriction analysis; the cultivar's chloroplast heteroplasmy is not transmitted during sexual reproduction but can be maintained through vegetative propagation (Chat et al., 2002). Chloroplasts can be heteroplastomic under selection pressure from spectinomycin in genetically transformed tobacco plants, which gradually eliminated the inserted DNA and returned to the wild-type plastome after the selection pressure (spectinomycin) was removed (Drescher et al., 2000).

Chloroplast mutation. Plastid division occurs by binary fission and not by meiosis. Therefore, plastid DNA evolution occurs through SGV and not through Mendelian genetic variation, even though Mendelian genetic variation of certain nuclear genes can impact chloroplast DNA variation. Many chloroplast genes, such as the transfer RNA genes trnC-GCA and trnN-GUU, are essential for plant cell development, as confirmed by an analysis of mutants (Legen et al., 2007). A chloroplast DNA mutation for changing a cytosine to an adenine in the $16 \mathrm{~S}$ ribosomal RNA is likely sufficient for the streptomycin resistance phenotype in Nicotiana tabacum (Etzold et al., 1987). Chloroplast DNA diversity is heritable and has been widely used in phylogeny, such as for genetic-distance analysis in wild and cultivated species of rice (Dally and Second, 1990). Because of the high copy number of the chloroplast genome and the much higher chance that they will be detected in highly degraded DNA, chloroplast DNA polymorphisms can be used in identifying or verifying plant sources in the food industry and forensic science (Taberlet et al., 2007). Early chloroplasts during endosymbiosis did not have chlorophyll $b$, and the generation of chlorophyll- $b$ containing chloroplasts during evolution appears to finetune oxygenic photosynthesis (Kim et al., 2009).

\section{Mitochondrial genome sequence or DNA amount variation}

Variation in mitochondrial DNA amount per cell or the ratio of mitochondrial to nuclear DNA. The mitochondrial genome per cell or the mtDNA and nuclear DNA amount ratio in plants is very dynamic in response to development and environmental conditions. In maize, for example, the immature yellowish part of functional leaves has more mtDNA in comparison with the dark green and more mature part of the same leaves; similarly, root tips have more mtDNA than the root elongation zone does (Ma and $\mathrm{Li}, 2015)$. It is known that mitochondrial transcript density is very different among different cell types and tissues ( $\mathrm{Li}$ et al., 1996). The recent study by Ma and Li (2015) indicates that the cellular difference in the functional genomics of mitochondria is not only at the transcript level but also at the level of the mtDNA, a finding that suggests that the copy numbers of mitochondrial chromosomes play a role in the cell-specific transcriptional activities of the mitochondrial genes. 
Stoichiometric variation of the ratio between mitochondrial subgenome molecules. Stoichiometric variation of the ratio between mitochondrial subgenome molecules (sublimons, mitochondrial chromosomes) was found to be involved in mitochondrial mutants showing cytoplasmic male sterility (CMS) in Nicotiana sylvestris (Li et al., 1988). The involvement of stoichiometric variation in CMS has now been confirmed in many plants, such as petunia (Yesodi et al., 1997) and common bean (Phaseolus) (Arrieta-Montiel et al., 2001). In Arabidopsis, the amplification and recombination of subgenomic mitochondrial molecules are affected by nuclear gene MHS1 and therefore by nuclear genetic background (Laser et al., 1997). Some mitochondrial genome mutants do not alter male fertility but are still heritable over generations and affect the height of plants (Li, 1987).

Homologous recombination of mitochondrial DNA. Recombination can occur between two repeated sequences of the mitochondrial genome in either somatic or sexual cells. Homologous recombination involving the mitochondrial cox2 gene is responsible for a mutation in the CMS-specific mitochondrial locus of petunia (Yesodi et al., 1997).

Mitochondrial gene mutation and inheritable DNA rearrangements. Mitochondrial gene mutation and inheritable DNA rearrangements due to DNA sequence changes occur in either somatic or sexual cells. Variant mitochondrial transcripts of a broad bean (Vicia faba) line are associated with two point mutations located upstream of the nad5 exon c (Scheepers et al., 1997). The mitochondrial point mutation rate is very low, as is the case with the mitochondrial genome of Magnolia stellata (Richardson et al., 2013). Mitochondrial genomes in most dairy animals such as cow and goat likely have the same evolutionary origin in terms of endosymbiosis, but each dairy animal species now has genome sequences that are distinct from those of other dairy species.

Mitochondrial plasmids. The mitochondria of some plants have plasmids, and mitochondrial plasmids are known to be maternally transmitted (Andersson-Ceplitis and Bengtsson, 2002). Some mitochondrial plasmids are suspected to be involved in CMS (Palmer et al., 1983). The copy number of mitochondrial plasmids appears to vary among nuclear genotypes in rapeseed (Brassica napus) (Erickson et al., 1986).

\section{DNA transfer, organelle transmission, and organelle genome segregation}

Horizontal transfer of DNA. Horizontal DNA transfer (also known as lateral DNA transfer) occurs in both nuclear and cytoplasmic genomes and in both somatic cells and sexual reproductive cells. The physical association between parasites and their hosts facilitates horizontal transfer. For example, about $2.1 \%$ of the nuclear gene transcripts in the holoparasite plant Rafflesia cantleyi (Rafflesiaceae) were likely acquired from its obligate host (Xi et al., 2013). Phylogenetic studies from diverse clades indicate that horizontal transfer to parasitic plants from their hosts is high in the mitochondrial genome and appreciable in the nuclear genome (Davis and $\mathrm{Xi}, 2015$ ). The transfer is not random, and mitochondrial genes are among the most frequently transferred ones. Eleven of 27 analyzed mitochondrial genes (approximately 41\%) in Rafflesia cantleyi were found to be horizontally transferred from the host plants (Xi et al., 2013).

Genetic transformation of the nuclear or chloroplast genome. Genetic transformation of either the nuclear genome (Bryant, 1986) or a chloroplast genome with DNA from either different genomic compartments of the species itself or a different species can occur both in nature and under controlled laboratory conditions. Most cultivars of sweet potato (Ipomoea batatas) from South and Central America, Africa, Asia, and Oceania naturally carry transferred DNA from Agrobacterium spp. (Kyndt et al., 2015). This natural genetic transformation likely occurs because sweet potato is propagated mainly through storage roots, and therefore, some root cells transformed by Agrobacterium strains in soil can have the opportunity to grow into individual clonal plants. DNA transfer can be greatly accelerated and made more accurate by using artificial, designed genetic engineering experiments. Genetic transformation of plant nuclear and chloroplast genomes with foreign DNA is greatly facilitated when it is mediated with an Agrobacterium species (Howe, 1985; Stachel et al., 1986). The transfer of Agrobacterium DNA to plants requires a transfer-DNA, or TDNA, border (Gardner and Knauf, 1986). A plant cell factor induces vir gene expression in Agrobacterium tumefaciens (Stachel et al., 1986). Cereals are more resistant to Agrobacteriummediated transformation, but the degree of resistance depends on which Agrobacterium tumefaciens stains and vir genes are used (Li et al., 1992; Liu et al., 1992). In a rice genetic transformation study, the present author and collaborators ( $\mathrm{Li}$ et al., 1992) used a potato gene intron in the marker gene gusA to ensure that the gusA gene expression occurred inside the plant cell, and they created Agrobacterium tumefaciens strain EHA105 by removing a kanamycin-resistant gene in the chromosome of strain EHA101. Those researchers obtained a very high rate of transient transformation in all of the eight indica (Oryza sativa var. indica) varieties, seven japonica (Oryza sativa var. japonica) varieties, and six African rice (Oryza glaberrima) varieties ( $\mathrm{Li}$ et al., 1992). The results obtained by those researchers confirmed that cereal crops can also be efficiently transformed; rice in nature can also likely be frequently transformed by Agrobacterium tumefaciens, although rice does not show the symptoms, mainly because cereals do not show tumors in infected tissues ( $\mathrm{Li}$ et al., 1992). The vir genes of an agropine-type Ti-plasmid of Agrobacterium tumefaciens EHA105 were most effective in directing gusA expression, whereas those of nopalinetype and octopine-type plasmids were less effective in genetically transforming rice ( $\mathrm{Li}$ et al., 1992). Additional copies of octopine- and agropine-type virG genes in Agrobacterium tumefaciens strains containing an agropinetype Ti-plasmid enhanced the frequency of transient transformation of celery and rice (Liu et al., 1992). 
Maternal transmission and occasional paternal transmission of plastids and mitochondria. Both plastids and mitochondria can be transmitted occasionally through pollen, although the organelles are usually inherited cytoplasmically in most plants. This paternal transmission has been detected by chloroplast DNA analysis in various plants (Medgyesy et al., 1986; Horlow et al., 1990; Stine and Keathley, 1990; Erickson and Kemble, 1993; Wang et al., 2004). Paternal transmission of mitochondria also occurs occasionally, such as in a cross between a female with nap-type cytoplasm and a male with pol-type cytoplasm in rapeseed (Brassica napus) (Erickson and Kemble, 1990, 1993). However, when Brassica rapa plants with fertile cytoplasm were used as female plants and crossed with partially male sterile plants carrying pol cytoplasm, the present author found that all of the several hundred plants were still fertile ( $\mathrm{Li}$, unpublished results). It is known that pol cytoplasm carries the CMS-associated mitochondrial gene orf224 (Singh et al., 1996; L'Homme et al., 1997; Li et al., 1998; Formanova et al., 2006). The present author made several crosses using a plant carrying the orf224 gene in the mitochondrial genome as the male parent and plants that lack the mitochondrial orf224 as the female parents, but the hybrid plants were not found to have any clear sign of the expression of this gene, if it indeed has some paternal transfer ( $\mathrm{Li}$, unpublished results).

Chloroplast genome segregation in somatic hybrids from protoplast fusion. The chloroplast genome in somatic hybrids from protoplast fusion is similar to one of the parents in some somatic hybrids, such as in the case of tobacco cybrids (Belliard et al., 1979; Patel et al., 2011). That is not always the case, however. For example, the somatic hybrids between the cultivated potato (Solanum tuberosum) and the wild potato species Solanum vernei exhibit a recombination in the chloroplast genomes from both parents (Trabelsi et al., 2005).

Genetic material exchanges between hosts and stable or temporary endosymbionts (viruses, endobacteria, or endofungi). Although the category encompassing endosymbiosis, viral infection, and endobacteria is often not a regular part of variation of the somatic nuclear and organelle genome, most genes of the nucleomorph genome and the chloroplast genome were transferred to the nuclear genome in certain algae during evolution (Curtis et al., 2012). The remaining nucleomorph and the chloroplast are likely still essential for these algae. Temporary endobacteria and parasitic viruses also add genetic materials to the cell, and their presence usually has a huge impact on cellular function and crop productivity (Hoffmeister and Martin, 2003; Gagne-Bourgue et al., 2013). Bacterial endophytes mediate the positive feedback effects of early legume termination times on the yield of subsequent durum wheat (Triticum turgidum var. durum) crops (Yang et al., 2012). A fungal endophyte was found to enhance the biomass production and essential oil yield of East Indian lemongrass (Cymbopogon flexuosus) (Ahmad et al., 2001). The transfer of DNA from endosymbionts contributes to the diversity and evolution of the nuclear genome (Hoffmeister and Martin, 2003), such as in the case of insects (Jiggins and Hurst, 2011). Elements from both retroviruses and nonretroviral RNA viruses have been found in many eukaryotic nuclear genomes, and mitovirus sequences have been found in plant mitochondrial genomes (Bruenn et al., 2015). Therefore, this category of changes to the cellular genome network can be loosely attributed to SGV. It is also known that some sea slugs (taxon Sacoglossa; Gastropoda: Opisthobranchia), which are invertebrate animals, survive for months solely on photosynthesis by the diet-derived chloroplasts captured from eating algae (Händeler et al., 2009). The example of sea slugs and chloroplasts suggests that some temporary endosymbionts in the genome network, regardless of whether there is DNA exchange, can also play a role in the growth and survival of the host organism.

\section{Intercompartmental variation}

Intercompartmental interaction at the genome level. There are numerous examples of intercompartmental interaction in the genome network ( $\mathrm{Li}$ et al., 1998; DellaPenna and Pogson, 2006; Formanova et al., 2006; Savage et al., 2013; Liu and Last, 2015). Chloroplasts not only are the organelles where photosynthesis takes place but also produce many compounds that are vital for cellular functions (DellaPenna and Pogson, 2006). Many chloroplast proteins, including some proteins involved in protecting cells from photodamage, are encoded by the nuclear genome (Savage et al., 2013; Liu and Last, 2015), whereas chloroplast genes are involved in the processing of both chloroplast-encoded and nuclear-gene-encoded chloroplast proteins (Johnson et al., 1991). Sometimes a single gene may have negative effects on plant growth but becomes important for helping plant performance and survival in natural and artificial selection when the gene forms a functional system with genes in another compartment in certain tissues. An example of such an interaction is the interaction between the mitochondrial genes for plant CMS and the nuclear genes for restoration of male fertility in Brassica napus (Li et al., 1998). These nuclear-mitochondrial genes tend to be eliminated in the population when they exist alone, but they survive natural and artificial selection and coevolve new CMS genes and their nuclear alleles to restore fertility (Li et al., 1998).

Intercompartmental exchanges of genetic materials. Intercompartmental exchanges of genetic materials occur between the nuclear, plastid, and mitochondrial genomes in both somatic and sexual cells. It has been found that chloroplast DNA is transferred quite frequently into the nuclear chromosomes of maize (Roark et al., 2010). The transfer of plastid DNA to the nucleus is elevated during male gametogenesis in tobacco (Sheppard et al., 2008). The transfer of a copy of some plastid DNA or mtDNA often gives rise to noncoding sequences, but some of these sequences were found to be recruited as exons (Kleine et al., 2009). Intercompartmental DNA transfer is considered a driving force for genome evolution (Kleine et al., 2009). The transfer of the mitochondrial ribosomal protein L6 gene to the nucleus was reported in rice and is likely mediated by a transposable element (Kubo et al., 2008). Even though many organelle genes are transferred to the nuclear genome, plastids and mitochondria retain the 
coding capacity of certain genes (Adams and Palmer, 2003; Daley and Whelan, 2005), suggesting that it is more beneficial for these genes to be encoded by the organelle genome during evolution in most species.

\section{Management of somatic genome variation, and concluding remarks}

For seed-propagated crops, cultivar maintenance should use seeds. Propagation using a non-seed approach, such as cell culture or repeated cuttings, for seed-propagated crops could result in SGV and epigenetic variation of the cultivar. Some of these variations, including major gene mutations, ploidy changes, or stoichiometric change of mitochondrial subgenomic molecules, may be inheritable as stable traits. However, most somagenetic variations, such as the organelle genome copy number per cell, repetitive DNA amount, or extrachromosomal DNA, may act similarly to physiological or epigenetic variations but can still be transgenerational through seeds or propagules and influence plant growth in the next generation. Somatic mutation is suspected to be involved in crop autogamy depression (cultivar degeneration) (Scofield, 2014). Somagenetic variation, not only the classical mutations but also the variation in repetitive sequence and nuclearorganelle interaction, is likely one of the commonly suspected causes of cultivar degeneration and therefore the gradual reduction in the human-preferred performance of cultivars. Environmentally induced SGV may not always improve the commercial value of crop cultivars, because the ability to survive in the environment is sometimes not in the same direction as commercially harvested value. For example, for cereals such as maize, breeders select large grains, maximized yield, and relatively short dormancy, whereas natural selection may prefer small grains, low yield, and long dormancy. Commercial production has certain levels of tolerance to SGV and trait variation, as long as the cultivar still has acceptable performance.

A propagation method can be used as long as the method for the cultivar has been selected through breeding and as long as the propagated plants still show acceptable performance in terms of yield or quality, although in vitro dedifferentiation and regeneration should be minimized or avoided for genotype resource maintenance due to the issue of somaclonal variation. In vitro cell culture holds great promise for rapidly propagating plants. For example, somatic embryos can be produced in bio-reactors on a large scale and be directly planted in potting mix as seeds if the somatic embryos are sufficiently developed and are appropriately encapsulated (Li, 1990). In the current system of potato production, potato clones are maintained in vitro as cuttings on a hormone-free medium or on a medium with a minimal amount of auxins, without the step of regeneration from calli. Microtubers are also widely used in potato propagation and botanical study (Donnelly et al., 2003; Nassar et al., 2008). These two approaches avoid the use of dedifferentiation and regeneration and therefore can effectively avoid most somaclonal variation as long as the propagule culture is not under rare stresses.

For vegetatively propagated crops, such as potato, SGV can be transferred to the new plants if the variation occurs in tuber buds or in the plantlets cultured in vitro. Chromosome doubling of diploid potato clones can effectively increase tuber size ( $\mathrm{Li}$ et al., 2014). The most widely used potato cultivar, 'Russet Burbank', is confirmed by DNA analysis to be a mutant of 'Burbank' (Bethke et al., 2014), demonstrating that using SGV can be an effective approach in potato breeding. 'Russet Burbank' was likely a periclinal chimera but, at least in a New Brunswick line, is not presently organized in a periclinal chimeral arrangement (Nassar et al., 2008), suggesting that ploidy SGV can have a certain instability even though the clone is maintained vegetatively.

Stability in inheritance and the transgenerational effects of various categories of SGV in seed-propagated crops are still far from clear because of the quite thorough reset during sexual reproduction. However, in vegetatively propagated crops such as cuttings for trees or tubers for potato, the developmental reset of somagenetic status is much less thorough, and agricultural performance such as growth characteristics, yield, and quality is selected for reproducibility over vegetative generations when plants are propagated by the same propagation method. Therefore, to minimize "cultivar degeneration" (decline in cultivar performance in terms of yield and quality) resulting from SGV, the vegetative propagules harvested for planting should be collected from plants that were managed under standard farming practices. If possible, the plants used for the production of vegetative propagules ("seed" potatoes), including the plantlet propagation stage, should be managed to avoid unnecessary stresses such as severe drought or salinity, unless the cultivar was selected under these stresses or will have to grow under these stresses.

With regard to crop management, crop rotation is likely an important means of avoiding the selective propagation and accumulation of mutant pathogen strains generated by pathogen gene conversion in monocultures. The use of transgeneration memory, for either SGV or epigenetic variation, may be valuable for training parental plants to enhance stress tolerance or change the tuberization date as long as the plants are still uniform, the yield is still acceptable, and the seeds or propagules do not transfer pathogens to the next generation. Field trials on a case-bycase basis are required prior to the use of training parental plants with biotic or abiotic stresses.

The somatic genome network formed by all the genetic materials in the nonreproductive cell has variations at different levels, including, for example, ploidy variation, stoichiometric variation, copy number variation, and mutation rate variation, as well as extrachromosomal DNA variation of both the nuclear and organelle genomes. Most SGV is programmed and beneficial to plant growth and development and should not be seriously disrupted. Some SGV can increase plant adaptation, which sometimes runs contrary to crop yield or quality objectives and therefore can cause cultivar degeneration in terms of agronomic performance. For cultivar performance stability, cultivar propagation should use the regular methods (e.g., sexual reproduction or vegetative propagation) that breeders used to generate seeds or propagules for cultivar trials. Past and 
current research is focused mainly on profiling SGV during development and under different environmental conditions. More research should be devoted to determining the natural laws governing the inheritance and optimization of SGV and therefore to developing suitable strategies for the use of SGV. One somatic breeding approach is to selectively improve certain aspects of an existing cultivar by using SGV while still maintaining the general genotype of the cultivar. After learning more about SGV, it may be possible to develop field- or greenhouse-growing or storage methods to improve crop yield and quality through the regulation of SGV before planting or during plant growth.

The somatic genome or the body's DNA of living organisms is not immune to changes and sometimes even requires having variations in order to support cell differentiation and individual development. The most investigated SGVs include DNA transposition, gene mutation, ploidy changes, DNA copy number variation, horizontal DNA transfer, and DNA rearrangement of genomes. The SGV list in this article is by no means to be complete. Further research will surely illustrate additional SGVs or underlying mechanisms. For example, the great increase of genome size during the increase of life complexity on earth ( $\mathrm{Li}$ and $\mathrm{Du}, 2014 \mathrm{~b})$ and the occurrence of novel sequences in plants have also raised the possibility of certain contributions from non-templated DNA synthesis (or nontemplated RNA synthesis) during evolution. Thanks to SGV research, we now view the genome very differently from the classical concept of the term, can appreciate the role of SGV in crop performance, and have developed somatic breeding approaches for plant improvement.

\section{References}

Adams, K.L., and Palmer, J.D. (2003). Evolution of mitochondrial gene content: Gene loss and transfer to the nucleus. Mol Phylogenet Evol 29, 380-395.

Ahmad, A., Alam, M., and Janardhanan, K.K. (2001). Fungal endophyte enhances biomass production and essential oil yield of East Indian lemongrass. Symbiosis 30, 275-285.

Andersson-Ceplitis, H., and Bengtsson, B.O. (2002). Transmission rates and phenotypic effects of mitochondrial plasmids and cytotypes in Silene vulgaris. Evolution 56, 1586-1591.

Anker, P., and Stroun, M. (2012). Circulating nucleic acids and evolution. Expert Opin Biol Ther 12, S113-S117.

Arrieta-Montiel, M., Lyznik, A., Woloszynska, M., Janska, H., Tohme, J., and Mackenzie, S. (2001). Tracing evolutionary and developmental implications of mitochondrial stoichiometric shifting in the common bean. Genetics 158, 851-864.

Bai, S.N. (2015). The concept of the sexual reproduction cycle and its evolutionary significance. Front Plant Sci 6, 11.

Barow, M., and Meister, A. (2003). Endopolyploidy in seed plants is differently correlated to systematics, organ, life strategy and genome size. Plant Cell Environ 26, 571-584.

Baumgartner, B.J., Rapp, J.C., and Mullet, J.E. (1989). Plastid transcription activity and DNA copy number increase early in barley chloroplast development. Plant Physiol 89, 1011-1018.

Belliard, G., Vedel, F., and Pelletier, G. (1979). Mitochondrial recombination in cytoplasmic hybrids of Nicotiana tabacum by protoplast fusion. Nature 281, 401-403.

Bennett, M.D., Finch, R.A., and Barclay, I.R. (1976). The time rate and mechanism of chromosome elimination in Hordeum hybrids. Chromosoma 54, 175-200.

Berchowitz, L.E., and Copenhaver, G.P. (2009). Visual markers for detecting gene conversion directly in the gametes of Arabidopsis thaliana. In Meiosis, Volume 1, Molecular and Genetic Methods, S. Keeney, ed., Methods in Molecular Biology, Book 557 (New York: Humana Press), pp. 99-114.

Bethke, P.C., Nassar, A.M.K., Kubow, S., Leclerc, Y.N., Li, X.-Q., Haroon, M., Molen, T., Bamberg, J., Martin, M., and Donnelly, D.J. (2014). History and origin of Russet Burbank (Netted Gem) a sport of Burbank. Am J Potato Res 91, 594-609.

Bianchi, G., Spinosi, K., and Marchi, P. (1997). Unstable Bchromosomes in Ranunculus bulbosus L. (Ranunculaceae). Caryologia 50, 17-29.

Bobadilla Landey, R., Cenci, A., Guyot, R., Bertrand, B., Georget, F., Dechamp, E., Herrera, J.-C., Aribi, J., Lashermes, P., and Etienne, H. (2015). Assessment of genetic and epigenetic changes during cell culture ageing and relations with somaclonal variation in Coffea arabica. Plant Cell Tissue Organ Cult 122, 517-531.

Bollhöner, B., Prestele, J., and Tuominen, H. (2012). Xylem cell death: Emerging understanding of regulation and function. J Exp Bot 63, 1081-1094.

Bordes, J., Dumas de Vaulx, R., Lapierre, A., and Pollacsek, M. (1997). Haplodiploidization of maize (Zea mays $\mathrm{L}$ ) through induced gynogenesis assisted by glossy markers and its use in breeding. Agronomie 17, 291-297.

Boyko, A., and Kovalchuk, I. (2011). Genome instability and epigenetic modification - Heritable responses to environmental stress? Curr Opin Plant Biol 14, 260-266.

Bozorgipour, R., and Snape, J.W. (1997). An assessment of somaclonal variation as a breeding tool for generating herbicide tolerant genotypes in wheat (Triticum aestivum L.). Euphytica 94, 335-340.

Bracht, J.R. (2016). RNA-mediated somatic genome rearrangement in ciliates. In Somatic Genome Variation in Animals, Plants and Microorganisms, X.-Q. Li, ed. (Wiley-Blackwell).

Bracht, J.R., Fang, W., Goldman, A.D., Dolzhenko, E., Stein, E.M., and Landweber, L.F. (2013). Genomes on the edge: Programmed genome instability in ciliates. Cell 152, 406-416.

Bruder, C.E.G., Piotrowski, A., Gijsbers, A.A.C.J., Andersson, R., Erickson, S., Diaz de Ståhl, T., Menzel, U., Sandgren, J., von Tell, D., Poplawski, A., et al. (2008). Phenotypically concordant and discordant monozygotic twins display different DNA copy-number-variation profiles. Am J Hum Genet 82, 763-771.

Bruenn, J.A., Warner, B.E., and Yerramsetty, P. (2015). Widespread mitovirus sequences in plant genomes. PeerJ 3, e876. 
Bryant, J.A. (1986). The role of host-bacterium interactions in the Agrobacterium-mediated transformation of plant cells. Trends Biotechnol 4, 131-132.

Cavallini, A., Natali, L., Polizzi, E., and Giordani, T. (1996). Variation of repetitive DNA sequences in progenies of regenerated plants of Pisum sativum. J Hered 87, 233-237.

Chamnanpunt, J., Shan, W., and Tyler, B.M. (2001). High frequency mitotic gene conversion in genetic hybrids of the oomycete Phytophthora sojae. Proc Natl Acad Sci USA 98, 14530-14535.

Chat, J., Decroocq, S., Decroocq, V., and Petit, R.J. (2002). A case of chloroplast heteroplasmy in kiwifruit (Actinidia deliciosa) that is not transmitted during sexual reproduction. J Hered 93, 293-300.

Chen, Y., Schneeberger, R.G., and Cullis, C.A. (2005). A site-specific insertion sequence in flax genotrophs induced by environment. New Phytol 167, 171-180.

Cheng, Y.J., Guo, W.W., and Deng, X.X. (2003). Molecular characterization of cytoplasmic and nuclear genomes in phenotypically abnormal Valencia orange (Citrus sinensis) + Meiwa kumquat (Fortunella crassifolia) intergeneric somatic hybrids. Plant Cell Rep 21, 445-451.

Chikwambi, Z., and Muchuweti, M. (2008). Isolation and identification of anthocyanins in the fruit peels of Starkrimson and Marx red Bartlett common pear cultivars and their bud mutants. Am J Food Technol 3, 1-12.

Cohen, S., Houben, A., and Segal, D. (2008). Extrachromosomal circular DNA derived from tandemly repeated genomic sequences in plants. Plant $\mathrm{J}$ 53, 1027-1034.

Coll, N.S., Epple, P., and Dangl, J.L. (2011). Programmed cell death in the plant immune system. Cell Death Differ 18, 1247-1256.

Comai, L. (2005). The advantages and disadvantages of being polyploid. Nat Rev Genet 6, 836-846.

Courtial, B., Feuerbach, F., Eberhard, S., Rohmer, L., Chiapello, H., Camilleri, C., and Lucas, H. (2001). Tnt1 transposition events are induced by in vitro transformation of Arabidopsis thaliana, and transposed copies integrate into genes. Mol Genet Genomics 265, 32-42.

Crété, P., Leuenberger, S., Iglesias, V.A., Suarez, V., Schöb, H., Holtorf, H., van Eeden, S., and Meins Jr, F. (2001). Graft transmission of induced and spontaneous post-transcriptional silencing of chitinase genes. Plant $\mathrm{J}$ 28, 493-501.

Cullis, C.A. (1973). DNA differences between flax genotrophs. Nature 243, 515-516.

Curtis, B.A., Tanifuji, G., Burki, F., Gruber, A., Irimia, M., Maruyama, S., Arias, M.C., Ball, S.G., Gile, G.H., Hirakawa, Y., et al. (2012). Algal genomes reveal evolutionary mosaicism and the fate of nucleomorphs. Nature 491, 59-65.

Daley, D.O., and Whelan, J. (2005). Why genes persist in organelle genomes. Genome Biol 6, 110.

Dally, A.M., and Second, G. (1990). Chloroplast DNA diversity in wild and cultivated species of rice (Genus Oryza, section Oryza). Cladistic-mutation and geneticdistance analysis. Theor Appl Genet 80, 209-222.
Damiani, F., Pezzotti, M., and Arcioni, S. (1990). Somaclonal variation in Lotus corniculatus $\mathrm{L}$. in relation to plant breeding purposes. Euphytica 46, 35-41.

Davis, C.C., and Xi, Z. (2015). Horizontal gene transfer in parasitic plants. Curr Opin Plant Biol 26, 14-19.

Del Pozo, J.C., Diaz-Trivino, S., Cisneros, N., and Gutierrez, C. (2006). The balance between cell division and endoreplication depends on E2FC-DPB, transcription factors regulated by the ubiquitinSCFSKP2A pathway in Arabidopsis. Plant Cell 18, 2224-2235.

DellaPenna, D., and Pogson, B.J. (2006). Vitamin synthesis in plants: Tocopherols and carotenoids. Annu Rev Plant Biol 57, 711-738.

Demarly, Y., and Sibi, M. (1989). Amélioration des plantes et biotechnologies (Paris: John Libbey Eurotext), 152 pages.

Diao, X., Freeling, M., and Lisch, D. (2006). Horizontal transfer of a plant transposon. PLoS Biol 4, e5.

Donnelly, D.J., Coleman, W.K., and Coleman, S.E. (2003). Potato microtuber production and performance: A review. Am J Potato Res 80, 103-115.

Drescher, A., Ruf, S., Calsa Jr, T., Carrer, H., and Bock, R. (2000). The two largest chloroplast genome-encoded open reading frames of higher plants are essential genes. Plant J 22, 97-104.

Du, D., Lee, C.F., and Li, X.-Q. (2012). Systematic differences in signal emitting and receiving revealed by PageRank analysis of a human protein interactome. PLoS ONE 7, e44872.

Erickson, L., Grant, I., and Beversdorf, W. (1986). Cytoplasmic male sterility in rapeseed (Brassica napus L.) - 2. The role of a mitochondrial plasmid. Theor Appl Genet 72, 151-157.

Erickson, L., and Kemble, R. (1990). Paternal inheritance of mitochondria in rapeseed (Brassica napus). Mol Gen Genet 222, 135-139.

Erickson, L., and Kemble, R. (1993). The effect of genotype on pollen transmission of mitochondria in rapeseed (Brassica napus). Sex Plant Reprod 6, 33-39.

Escaravage, N., Questiau, S., Pornon, A., Doche, B., and Taberlet, P. (1998). Clonal diversity in a Rhododendron ferrugineum L. (Ericaceae) population inferred from AFLP markers. Mol Ecol 7, 975-982.

Etzold, T., Fritz, C.C., Schell, J., and Schreier, P.H. (1987). A point mutation in the chloroplast $16 \mathrm{~S}$ rRNA gene of a streptomycin resistant Nicotiana tabacum. FEBS Lett 219, 343-346.

Evans, D.A., and Paddock, E.F. (1977). X-ray induced increase of mitotic crossovers in Nicotiana tabacum. Environ Exp Bot 17, 99-106.

Evans, L.S., Tramontano, W.A., and Gill, R. (1987). A natural substance that regulates the cell cycle in complex plant tissues. Phytochemistry 26, 2891-2893.

Formanova, N., Li, X.-Q., Ferrie, A.M.R., DePauw, M., Keller, W.A., Landry, B., and Brown, G.G. (2006). Towards positional cloning in Brassica napus: Generation and analysis of doubled haploid $B$. rapa possessing the $B$. napus pol CMS and Rfp nuclear restorer gene. Plant Mol Biol 61, 269-281.

Fuentes, I., Stegemann, S., Golczyk, H., Karcher, D., and Bock, R. (2014). Horizontal genome transfer as an 
asexual path to the formation of new species. Nature $511,232-235$.

Fulgosi, H., Ježić, M., Lepeduš, H., Štefanić, P.P., Ćurković-Perica, M., and Cesar, V. (2012). Degradation of chloroplast DNA during natural senescence of maple leaves. Tree Physiol 32, 346-354.

Gagne-Bourgue, F., Aliferis, K.A., Seguin, P., Rani, M., Samson, R., and Jabaji, S. (2013). Isolation and characterization of indigenous endophytic bacteria associated with leaves of switchgrass (Panicum virgatum L.) cultivars. J Appl Microbiol 114, 836-853.

Gardner, R.C., and Knauf, V.C. (1986). Transfer of Agrobacterium DNA to plants requires a T-DNA border but not the virE locus. Science 231, 725-727.

Geiger, H.H., and Gordillo, G.A. (2009). Doubled haploids in hybrid maize breeding. Maydica 54, 485-499.

Gibbs, S.P., Mak, R., Ng, R., and Slankis, T. (1974). The chloroplast nucleoid in Ochromonas danica. II. Evidence for an increase in plastid DNA during greening. J Cell Sci 16, 579-591.

Gichner, T., Lovecká, P., Kochánková, L., Macková, M., and Demnerová, K. (2007). Monitoring toxicity, DNA damage, and somatic mutations in tobacco plants growing in soil heavily polluted with polychlorinated biphenyls. Mutat Res/Genet Toxicol Environ Mutagen 629, 1-6.

Gordillo, G.A., and Geiger, H.H. (2008). Alternative recurrent selection strategies using doubled haploid lines in hybrid maize breeding. Crop Sci 48, 911-922.

Guerra, M. (2001). Fluorescent in situ hybridization in plant polytene chromosomes. Methods Cell Sci 23, 133-138.

Gunawardena, A.H.L.A.N., Greenwood, J.S., and Dengler, N.G. (2004). Programmed cell death remodels lace plant leaf shape during development. Plant Cell 16, 60-73.

Händeler, K., Grzymbowski, Y.P., Krug, P.J., and Wägele, $H$. (2009). Functional chloroplasts in metazoan cells - A unique evolutionary strategy in animal life. Front Zool 6 , 28.

Hanifi-Mekliche, L., and Gallais, A. (1999). Heterosis, genetic effects and value of $\mathrm{F}_{2} \mathrm{~S}$ and doubled-haploid lines in barley breeding. Agronomie 19, 509-520.

Hartung, F., Suer, S., Knoll, A., Wurz-Wildersinn, R., and Puchta, H. (2008). Topoisomerase $3 \alpha$ and RMI1 suppress somatic crossovers and are essential for resolution of meiotic recombination intermediates in Arabidopsis thaliana. PLoS Genet 4, e1000285.

Hoffmeister, M., and Martin, W. (2003). Interspecific evolution: Microbial symbiosis, endosymbiosis and gene transfer. Environ Microbiol 5, 641-649.

Horlow, C., Goujaud, J., Lépingle, A., Missonier, C., and Bourgin, J.P. (1990). Transmission of paternal chloroplasts in tobacco (Nicotiana tabacum). Plant Cell Rep 9, 249-252.

Hosaka, K. (1999). A genetic map of Solanum phureja clone 1.22 constructed using RFLP and RAPD markers. Am J Potato Res 76, 97-102.

Hovav, R., Udall, J.A., Chaudhary, B., Rapp, R., Flagel, L., and Wendel, J.F. (2008). Partitioned expression of duplicated genes during development and evolution of a single cell in a polyploid plant. Proc Natl Acad Sci USA 105, 6191-6195.

Howe, C. (1985). Chloroplast transformation by Agrobacterium tumefaciens. Trends Genet 1, 217-218.
Huang, C.R.L., Burns, K.H., and Boeke, J.D. (2012). Active transposition in genomes. Annu Rev Genet 46, 651-675.

Ishii, T., Ueda, T., Tanaka, H., and Tsujimoto, H. (2010). Chromosome elimination by wide hybridization between Triticeae or oat plant and pearl millet: Pearl millet chromosome dynamics in hybrid embryo cells. Chromosome Res 18, 821-831.

James, E.A., and McDougall, K.L. (2014). Spatial genetic structure reflects extensive clonality, low genotypic diversity and habitat fragmentation in Grevillea renwickiana (Proteaceae), a rare, sterile shrub from south-eastern Australia. Ann Bot 114, 413-423.

Jiggins, F.M., and Hurst, G.D.D. (2011). Rapid insect evolution by symbiont transfer. Science 332, 185-186.

Jiménez, S., Li, Z., Reighard, G.L., and Bielenberg, D.G. (2010). Identification of genes associated with growth cessation and bud dormancy entrance using a dormancy-incapable tree mutant. BMC Plant Biol 10, 25.

Johnson, E.M., Schnabelrauch, L.S., and Sears, B.B. (1991). A plastome mutation affects processing of both chloroplast and nuclear DNA-encoded plastid proteins. Mol Gen Genet 225, 106-112.

Khasdan, V., Yaakov, B., Kraitshtein, Z., and Kashkush, K. (2010). Developmental timing of DNA elimination following allopolyploidization in wheat. Genetics 185, 387-390.

Kidwell, K.K., and Osborn, T.C. (1993). Variation among alfalfa somaclones in copy number of repeated DNA sequences. Genome 36, 906-912.

Kilian, A., Stiff, C., and Kleinhofs, A. (1995). Barley telomeres shorten during differentiation but grow in callus culture. Proc Natl Acad Sci USA 92, 9555-9559.

Kim, E.-H., Li, X.-P., Razeghifard, R., Anderson, J.M., Niyogi, K.K., Pogson, B.J., and Chow, W.S. (2009). The multiple roles of light-harvesting chlorophyll $a / b$-protein complexes define structure and optimize function of Arabidopsis chloroplasts: A study using two chlorophyll $b$ less mutants. Biochim Biophys Acta 1787, 973-984.

Kim, N., and Jinks-Robertson, S. (2012). Transcription as a source of genome instability. Nat Rev Genet 13, 204-214.

Kinoshita, Y., Ohnishi, N., Yamada, Y., Kunisada, T., and Yamagishi, H. (1985). Extrachromosomal circular DNA from nuclear fraction of higher plants. Plant Cell Physiol 26, 1401-1409.

Kisby, G.E., Muniz, J.F., Scherer, J., Lasarev, M.R., Koshy, M., Kow, Y.W., and McCauley, L. (2009). Oxidative stress and DNA damage in agricultural workers. J Agromed 14, 206-214.

Kleine, T., Maier, U.G., and Leister, D. (2009). DNA transfer from organelles to the nucleus: The idiosyncratic genetics of endosymbiosis. Annu Rev Plant Biol 60, 115-138.

Kotogány, E., Dudits, D., Horváth, G.V., and Ayaydin, F. (2010). A rapid and robust assay for detection of S-phase cell cycle progression in plant cells and tissues by using ethynyl deoxyuridine. Plant Methods 6, 5.

Kubo, N., Fujimoto, M., Arimura, S., Hirai, M., and Tsutsumi, N. (2008). Transfer of rice mitochondrial ribosomal protein L6 gene to the nucleus: Acquisition of the 5'-untranslated region via a transposable element. BMC Evol Biol 8, e314. 
Kumar, R.A., Oldenburg, D.J., and Bendich, A.J. (2014). Changes in DNA damage, molecular integrity, and copy number for plastid DNA and mitochondrial DNA during maize development. J Exp Bot 65, 6425-6439.

Kyndt, T., Quispe, D., Zhai, H., Jarret, R., Ghislain, M., Liu, Q., Gheysen, G., and Kreuze, J.F. (2015). The genome of cultivated sweet potato contains Agrobacterium TDNAs with expressed genes: An example of a naturally transgenic food crop. Proc Natl Acad Sci USA 112, 5844-5849.

L'Homme, Y., Stahl, R.J., Li, X.-Q., Hameed, A., and Brown, G.G. (1997). Brassica nap cytoplasmic male sterility is associated with expression of a mtDNA region containing a chimeric gene similar to the pol CMSassociated orf224 gene. Curr Genet 31, 325-335.

Larkin, P.J., and Scowcroft, W.R. (1981). Somaclonal variation - A novel source of variability from cell cultures for plant improvement. Theor Appl Genet 60, 197-214.

Laser, B., Mohr, S., Odenbach, W., Oettler, G., and Kück, U. (1997). Parental and novel copies of the mitochondrial orf25 gene in the hybrid crop-plant triticale: Predominant transcriptional expression of the maternal gene copy. Curr Genet 32, 337-347.

Legen, J., Wanner, G., Herrmann, R.G., Small, I., and Schmitz-Linneweber, C. (2007). Plastid tRNA Genes trnC-GCA and trnN-GUU are essential for plant cell development. Plant J 51, 751-762.

$\mathrm{Li}, \mathrm{X} . \mathrm{Q}$. (1987). Variabilité après culture in vitro: étude génétique à partir de culture de protoplastes chez Nicotiana sylvestris, description des plantes régénérées chez Medicago lupulina. Docteur d'état (Paris (Orsay): Université Paris-Sud XI), 161 pages.

Li, X.-Q. (1990). Studies on artificial seeds of plants. Peking University Press, Beijing.

Li, X.-Q. (2008). Nature, extent and developmental regulation of somagenetic variations. CAB Rev: Perspect Agric Vet Sci Nutri Natur Resour 3, 031.

Li, X.-Q. (2009). Developmental and environmental variation in genomes. Heredity 102, 323-329.

$\mathrm{Li}, \mathrm{X} . \mathrm{Q}$. (2015a). Bioinformatic approaches for analysis of gene direction, chromosome base composition, mRNA polyadenylation, and protein network. In Somatic Genome Manipulation: Advances, Methods and Applications, X.-Q. Li, D.J. Donnelly, and T.G. Jensen, eds. (New York: Springer), pp. 353-363.

Li, X.-Q. (2015b). Laboratory methods for investigating nuclear and cytoplasmic genomes and transcriptome. In Somatic Genome Manipulation: Advances, Methods and Applications, X.-Q. Li, D.J. Donnelly, and T.G. Jensen, eds. (New York: Springer), pp. 323-352.

$\mathrm{Li}, \mathrm{X} . \mathrm{-Q}$. (2016). Impacts of somatic genome variation on genetic theories and breeding concepts. In Somatic Genome Variation in Animals, Plants and Microorganisms, X.-Q. Li, ed. (New York: WileyBlackwell). In press.

Li, X.-Q., Chetrit, P., Mathieu, C., Vedel, F., De Paepe, R., Remy, R., and Ambard-Bretteville, F. (1988). Regeneration of cytoplasmic male sterile protoclones of Nicotiana sylvestris with mitochondrial variations. Curr Genet 13, 261-266.

Li, X.-Q., and Du, D. (2012). Gene direction in living organisms. Sci Rep 2, 982.
Li, X.-Q., and Du, D. (2014a). Motif types, motif locations and base composition patterns around the RNA polyadenylation site in microorganisms, plants and animals. BMC Evol Biol 14, 162.

Li, X.-Q., and Du, D. (2014b). Variation, evolution, and correlation analysis of $C+G$ content and genome or chromosome size in different kingdoms and phyla. PLoS ONE 9, e88339.

Li, X.-Q., Haroon, M., Coleman, S.E., Sullivan, A., Singh, M., Ward, L., De Boer, S.H., Zhang, T., and Donnelly, D.J. (2008). A simplified procedure for verifying and identifying potato cultivars using multiplex PCR. Can J Plant Sci 88, 583-592.

Li, X.-Q., Jean, M., Landry, B.S., and Brown, G.G. (1998). Restorer genes for different forms of Brassica cytoplasmic male sterility map to a single nuclear locus that modifies transcripts of several mitochondrial genes. Proc Natl Acad Sci USA 95, $10032-10037$.

Li, X.-Q., Liu, C.-N., Ritchie, S.W., Peng, J., Gelvin, S.B., and Hodges, T.K. (1992). Factors influencing Agrobacterium-mediated transient expression of gus $A$ in rice. Plant Mol Biol 20, 1037-1048.

Li, X.-Q., Prat, D., De Paepe, R., and Pernes, J. (1985). Variability induced in Nicotiana sylvestris by two successive cycles of protoplast culture. Genet Manip Crops Newsl 1, 81-84.

Li, X.-Q., Xing, T., and Du, D. (2016). Identification of topranked proteins within a directional protein interaction network using the PageRank algorithm: Applications in humans and plants. Curr Issues Mol Biol 20, 13-28.

Li, X.-Q., Zhang, J., Allaby, S., Haroon, M., Murphy, A., Liu, G.S., Donnelly, D.J., and Leclerc, Y.N. (2014). Ploidy effects on potato starch granule size. Am J Potato Res 91, 53 (abstract).

Li, X.-Q., Zhang, M., and Brown, G.G. (1996). Cell-specific expression of mitochondrial transcripts in maize seedlings. Plant Cell 8, 1961-1975.

Linde-Laursen, I., and von Bothmer, R. (1988). Elimination and duplication of particular Hordeum vulgare chromosomes in aneuploid interspecific Hordeum hybrids. Theor Appl Genet 76, 897-908.

Liu, C.-A., and Douches, D.S. (1993). Production of haploids of potato (Solanum tuberosum subsp. tuberosum) and their identification with electrophoretic analysis. Euphytica 70, 113-126.

Liu, C.-N., Li, X.-Q., and Gelvin, S.B. (1992). Multiple copies of virG enhance the transient transformation of celery, carrot and rice tissues by Agrobacterium tumefaciens. Plant Mol Biol 20,1071-1087.

Liu, J., and Last, R.L. (2015). A land plant-specific thylakoid membrane protein contributes to photosystem II maintenance in Arabidopsis thaliana. Plant $\mathrm{J} 82$, 731-743.

Liu, Y.-S., Wang, Q.-L., and Li, B.-Y. (2010). New insights into plant graft hybridization. Heredity 104, 1-2.

Loxdale, H.D., Vorwerk, S., and Forneck, A. (2013). The unstable 'clone': Evidence from monitoring AFLP-based mutations for short-term clonal genetic variation in two asexual lineages of the grain aphid, Sitobion avenae (F.). Bull Entomol Res 103, 111-118.

Ma, J., and Li, X.-Q. (2015). Organellar genome copy number variation and integrity during moderate 
maturation of roots and leaves of maize seedlings. Curr Genet 61, 591-600.

Ma, Y., and Berkowitz, G.A. (2011). Danger at your door: Pathogen signals and programmed cell death in plants. New Phytol 192, 1-3.

Maruyama, D., Völz, R., Takeuchi, H., Mori, T., Igawa, T., Kurihara, D., Kawashima, T., Ueda, M., Ito, M., Umeda, M., et al. (2015). Rapid elimination of the persistent synergid through a cell fusion mechanism. Cell 161, 907-918.

McClintock, B. (1950). The origin and behavior of mutable loci in maize. Proc Natl Acad Sci USA 36, 344-355.

McCoy, T.J., and Rowe, D.E. (1986). Single cross alfalfa (Medicago sativa L.) hybrids produced via $2 \mathrm{n}$ gametes and somatic chromosome doubling: Experimental and theoretical comparisons. Theor Appl Genet 72, 80-83.

Meagher, T.R., and Vassiliadis, C. (2005). Phenotypic impacts of repetitive DNA in flowering plants. New Phytol 168, 71-80.

Medgyesy, P., Páy, A., and Márton, L. (1986). Transmission of paternal chloroplasts in Nicotiana. Mol Gen Genet 204, 195-198.

Medini, D., Donati, C., Tettelin, H., Masignani, V., and Rappuoli, R. (2005). The microbial pan-genome. Curr Opin Genet Dev 15, 589-594.

Melchinger, A.E., Schipprack, W., Würschum, T., Chen, S., and Technow, F. (2013). Rapid and accurate identification of in vivo-induced haploid seeds based on oil content in maize. Sci Rep 3, 2129.

Migicovsky, Z., and Kovalchuk, I. (2014). Transgenerational changes in plant physiology and in transposon expression in response to UV-C stress in Arabidopsis thaliana. Plant Signal Behav 9, e976490.

Nair, R.R. (2007). Aneuploid variation of chromosome number in the somatic cells of Piper magnificum Trel. Cytologia 72, 239-242.

Nakano, K., Lapirattanakul, J., Nomura, R., Nemoto, H., Alaluusua, S., Grönroos, L., Vaara, M., Hamada, S., Ooshima, T., and Nakagawa, I. (2007). Streptococcus mutans clonal variation revealed by multilocus sequence typing. J Clin Microbiol 45, 2616-2625.

Nassar, A.M.K., Abdulnour, J., Leclerc, Y., Li, X.-Q., and Donnelly, D.J. (2011). Intraclonal selection for improved processing of NB 'Russet Burbank' potato. Am J Potato Res 88, 387-397.

Nassar, A.M.K., Ortiz-Medina, E., Leclerc, Y., and Donnelly, D.J. (2008). Periclinal chimeral status of New Brunswick 'Russet Burbank' potato. Am J Potato Res 85, 432-437.

Navrátilová, A., Kobližková, A., and Macas, J. (2008). Survey of extrachromosomal circular DNA derived from plant satellite repeats. BMC Plant Biol 8, 90.

Osborne, D.J., and Boubriak, I. (2002). Telomeres and their relevance to the life and death of seeds. Crit Rev Plant Sci 21, 127-141.

Pajerowska-Mukhtar, K., and Dong, X. (2009). A kiss of death-Proteasome-mediated membrane fusion and programmed cell death in plant defense against bacterial infection. Genes Dev 23, 2449-2454.

Palmer, J.D., Shields, C.R., Cohen, D.B., and Orton, T.J. (1983). An unusual mitochondrial DNA plasmid in the genus Brassica. Nature 301, 725-728.
Pan, Z., An, J., Zeng, W., Xiao, S., and Deng, X. (2012). Array-comparative genome hybridization reveals genome variations between a citrus bud mutant and its parental cultivar. Tree Genet Genomes 8, 1379-1387.

Pan, Z., Li, Y., Deng, X., and Xiao, S. (2014). Non-targeted metabolomic analysis of orange (Citrus sinensis [L.] Osbeck) wild type and bud mutant fruits by direct analysis in real-time and HPLC-electrospray mass spectrometry. Metabolomics 10, 508-523.

Pandey, K.K. (1983). Evidence for gene transfer by the use of sublethally irradiated pollen in Zea mays and theory of occurrence by chromosome repair through somatic recombination and gene conversion. Mol Gen Genet 191, 358-365.

Paszkowski, J. (2015). Controlled activation of retrotransposition for plant breeding. Curr Opin Biotechnol 32, 200-206.

Patel, D., Power, J.B., Anthony, P., Badakshi, F., HeslopHarrison, J.S., and Davey, M.R. (2011). Somatic hybrid plants of Nicotiana $\times$ sanderae $(+) N$. debneyi with fungal resistance to Peronospora tabacina. Ann Bot 108, 809-819.

Paz, M.M., and Veilleux, R.E. (1999). Influence of culture medium and in vitro conditions on shoot regeneration in Solanum phureja monoploids and fertility of regenerated doubled monoploids. Plant Breed 118, 53-57.

Pérez-Vargas, J., Krey, T., Valansi, C., Avinoam, O., Haouz, A., Jamin, M., Raveh-Barak, H., Podbilewicz, B., and Rey, F.A. (2014). Structural basis of eukaryotic cell-cell fusion. Cell 157, 407-419.

Press, M.O., Carlson, K.D., and Queitsch, C. (2014). The overdue promise of short tandem repeat variation for heritability. Trends Genet 30, 504-512.

Puertas, M.J. (2002). Nature and evolution of B chromosomes in plants: A non-coding but informationrich part of plant genomes. Cytogenet Genome Res 96, 198-205.

Rauwolf, U., Golczyk, H., Greiner, S., and Herrmann, R.G. (2010). Variable amounts of DNA related to the size of chloroplasts III. Biochemical determinations of DNA amounts per organelle. Mol Genet Genomics 283, 35-47.

Reuscher, S., Isuzugawa, K., Kawachi, M., Oikawa, A., and Shiratake, K. (2014). Comprehensive elemental analysis of fruit flesh from European pear 'La France' and its giant fruit bud mutant indicates specific roles for $\mathrm{B}$ and $\mathrm{Ca}$ in fruit development. Sci Hortic 176, 255-260.

Richardson, A.O., Rice, D.W., Young, G.J., Alverson, A.J., and Palmer, J.D. (2013). The "fossilized" mitochondrial genome of Liriodendron tulipifera: Ancestral gene content and order, ancestral editing sites, and extraordinarily low mutation rate. BMC Biol 11, 29.

Roark, L.M., Hui, A.Y., Donnelly, L., Birchler, J.A., and Newton, K.J. (2010). Recent and frequent insertions of chloroplast DNA into maize nuclear chromosomes. Cytogenet Genome Res 129, 17-23.

Rogers, S.O., and Bendich, A.J. (1987). Ribosomal RNA genes in plants: Variability in copy number and in the intergenic spacer. Plant Mol Biol 9, 509-520.

Roncuzzi, L., Fadda, S., Mochi, M., Prosperi, L., Sangiorgi, S., Santamaria, R., Sbarra, D., Besana, D., Morandi, L., Rocchi, M., et al. (1985). Mapping of X-linked Becker muscular dystrophy through crossovers identified by 
DNA polymorphisms and by haplotype characterization in somatic cell hybrids. Am J Hum Genet 37, 407-417.

Salzman, V., Porro, V., Bollati-Fogolín, M., and Aguilar, P.S. (2015). Quantitation of yeast cell-cell fusion using multicolor flow cytometry. Cytometry A 87, 843-854.

Samitsu, Y., and Hosaka, K. (2002). Molecular marker analysis of 24- and 25-chromosome plants obtained from Solanum tuberosum L. subsp. andigena $(2 n=4 x=48)$ pollinated with a Solanum phureja haploid inducer. Genome 45, 577-583.

Sanam'yan, M.F., and Musaev, D.A. (1990). Detection and cytological study of the aneuploid and euploid plants with translocations of chromosomes in cotton Gossypium hirsutum L. Genetika 26, 506-515.

Savage, L.J., Imre, K.M., Hall, D.A., and Last, R.L. (2013). Analysis of essential Arabidopsis nuclear genes encoding plastid-targeted proteins. PLoS ONE 8, e73291.

Scheepers, D., Luo, H., and Boutry, M. (1997). Variant mitochondrial transcripts of a broad bean line are associated with two point mutations located upstream of the nad5 exon c. Plant Sci 129, 203-212.

Schneeberger, R.G., and Cullis, C.A. (1991). Specific DNA alterations associated with the environmental induction of heritable changes in flax. Genetics 128, 619-630.

Schubert, I., Oud, O.J.L., and Pich, U. (1998). Unscheduled apoptosis in meristematic plant cells is triggered via terminal deletions in artificially elongated chromosome arms. Theor Appl Genet 96, 1022-1026.

Schubert, I., and Wobus, U. (1985). In situ hybridization confirms jumping nucleolus organizing regions in Allium. Chromosoma 92, 143-148.

Schubert, L., and Lohmann, K. (1982). Indications for changes in DNA composition correlated with early embryonic differentiation (Triturus vulgaris, Urodela). Dev Growth Differ 24, 25-38.

Schubert, V., Kim, Y.M., Berr, A., Fuchs, J., Meister, A., Marschner, S., and Schubert, I. (2007). Random homologous pairing and incomplete sister chromatid alignment are common in angiosperm interphase nuclei. Mol Genet Genomics 278, 167-176.

Scofield, D.G. (2014). A definitive demonstration of fitness effects due to somatic mutation in a plant. Heredity 112 , 361-362.

Sheppard, A.E., Ayliffe, M.A., Blatch, L., Day, A., Delaney, S.K., Khairul-Fahmy, N., Li, Y., Madesis, P., Pryor, A.J., and Timmis, J.N. (2008). Transfer of plastid DNA to the nucleus is elevated during male gametogenesis in tobacco. Plant Physiol 148, 328-336.

Singh, M., Hamel, N., Menassa, R., Li, X.-Q., Young, B., Jean, M., Landry, B.S., and Brown, G.G. (1996). Nuclear genes associated with a single Brassica CMS restorer locus influence transcripts of three different mitochondrial gene regions. Genetics 143, 505-516.

Siroky, J., Zluvova, J., Riha, K., Shippen, D.E., and Vyskot, B. (2003). Rearrangements of ribosomal DNA clusters in late generation telomerase-deficient Arabidopsis. Chromosoma 112, 116-123.

Slabý, K., Šebánek, J., and Psota, V. (1990). The release of primordia of marginal buds on Bryophyllum crenatum leaves from growth inhibition in relationship to the level of endogenous IAA. Biol Plant 32, 352-356.
Smith, J.S.C., Hussain, T., Jones, E.S., Graham, G., Podlich, D., Wall, S., and Williams, M. (2008). Use of doubled haploids in maize breeding: Implications for intellectual property protection and genetic diversity in hybrid crops. Mol Breed 22, 51-59.

Song, H., Liu, D., Chen, X., Ying, Z., Zhang, B., Li, F., and $\mathrm{Lu}, \quad H$. (2010). Change of season-specific telomere lengths in Ginkgo biloba L. Mol Biol Rep 37, 819-824.

Stachel, S.E., Nester, E.W., and Zambryski, P.C. (1986). A plant cell factor induces Agrobacterium tumefaciens vir gene expression. Proc Natl Acad Sci USA 83, 379-383.

Stegemann, S., and Bock, R. (2009). Exchange of genetic material between cells in plant tissue grafts. Science $324,649-651$.

Stine, M., and Keathley, D.E. (1990). Paternal inheritance of plastids in Engelmann spruce $\mathrm{x}$ blue spruce hybrids. J Hered 81, 443-446.

Sun, M., Li, P., and Zhang, Q.-X. (2007). Flower color and florescence mutants obtained using electron beam irradiation of chrysanthemum buds. Acta Hortic 760, 667-672.

Suter, L., and Widmer, A. (2013). Environmental heat and salt stress induce transgenerational phenotypic changes in Arabidopsis thaliana. PLoS ONE 8, e60364.

Taberlet, P., Coissac, E., Pompanon, F., Gielly, L., Miquel, C., Valentini, A., Vermat, T., Corthier, G., Brochmann, C., and Willerslev, E. (2007). Power and limitations of the chloroplast trnL (UAA) intron for plant DNA barcoding. Nucleic Acids Res 35, e14.

Thyssen, G., Svab, Z., and Maliga, P. (2012). Cell-to-cell movement of plastids in plants. Proc Natl Acad Sci USA 109, 2439-2443.

Trabelsi, S., Gargouri-Bouzid, R., Vedel, F., Nato, A., Lakhoua, L., and Drira, N. (2005). Somatic hybrids between potato Solanum tuberosum and wild species Solanum verneï exhibit a recombination in the plastome. Plant Cell Tissue Organ Cult 83, 1-11.

Trivers, R., Burt, A., and Palestis, B.G. (2004). B chromosomes and genome size in flowering plants. Genome 47, 1-8.

Udy, D.B., Belcher, S., Williams-Carrier, R., Gualberto, J.M., and Barkan, A. (2012). Effects of reduced chloroplast gene copy number on chloroplast gene expression in maize. Plant Physiol 160, 1420-1431.

Urbanek, A., Szadziewski, R., Giłka, W., and Borkent, A. (2013). First description of polytene chromosomes in biting midges (Diptera: Ceratopogonidae). J Med Entomol 50, 458-461.

Vasil'Ev, L.A., Dzyubinskaya, E.V., Kiselevsky, D.B., Shestak, A.A., and Samuilov, V.D. (2011). Programmed cell death in plants: Protective effect of mitochondrialtargeted quinones. Biochemistry (Moscow) 76, $1120-1130$.

Wang, T., Li, Y., Shi, Y., Reboud, X., Darmency, H., and Gressel, J. (2004). Low frequency transmission of a plastid-encoded trait in Setaria italica. Theor Appl Genet 108, 315-320.

Wang, Y., Loake, G.J., and Chu, C. (2013). Cross-talk of nitric oxide and reactive oxygen species in plant programed cell death. Front Plant Sci 4, 314.

Waterer, D., Elsadr, H., and McArthur, M.-L. (2011). Skin color, scab sensitivity and field performance of lines 
derived from spontaneous chimeras of Red Norland potato. Am J Potato Res 88, 199-206.

Watson, I.R., Takahashi, K., Futreal, P.A., and Chin, L. (2013). Emerging patterns of somatic mutations in cancer. Nat Rev Genet 14, 703-718.

Wegenast, T., Longin, C.F.H., Utz, H.F., Melchinger, A.E., Maurer, H.P., and Reif, J.C. (2008). Hybrid maize breeding with doubled haploids. IV. Number versus size of crosses and importance of parental selection in twostage selection for testcross performance. Theor Appl Genet 117, 251-260.

Wei, L., Nakajima, S., Böhm, S., Bernstein, K.A., Shen, Z., Tsang, M., Levine, A.S., and Lan, L. (2015). DNA damage during the G0/G1 phase triggers RNAtemplated, Cockayne syndrome B-dependent homologous recombination. Proc Natl Acad Sci USA 112, E3495-E3504.

Xi, Z., Wang, Y., Bradley, R.K., Sugumaran, M., Marx, C.J., Rest, J.S., and Davis, C.C. (2013). Massive mitochondrial gene transfer in a parasitic flowering plant clade. PLoS Genet 9, e1003265.

Xiang, H., and Li, X.-Q. (2015). Development of TBSPG pipelines for refining unique mapping and repetitive sequence detection using the two halves of each Illumina sequence read. Plant Mol Biol Rep, DOI: 10.1007/ s11105-015-0912-8.

Xu, P.Z., Yuan, S., Li, Y., Zhang, H.Y., Wang, X.D., Lin, H.H., and Wu, X.J. (2007). Genome-wide high-frequency non-Mendelian loss of heterozygosity in rice. Genome 50, 297-302.

Xu, X., Pan, S., Cheng, S., Zhang, B., Mu, D., Ni, P., Zhang, G., Yang, S., Li, R., Wang, J., et al. (2011). Genome sequence and analysis of the tuber crop potato. Nature 475, 189-195.

Yamaguchi, H., Shimizu, A., Hase, Y., Degi, K., Tanaka, A., and Morishita, T. (2009). Mutation induction with ion beam irradiation of lateral buds of chrysanthemum and analysis of chimeric structure of induced mutants. Euphytica 165, 97-103.

Yan, S., Wang, W., Marqués, J., Mohan, R., Saleh, A., Durrant, W.E., Song, J., and Dong, X. (2013). Salicylic acid activates DNA damage responses to potentiate plant immunity. Mol Cell 52, 602-610.

Yang, C., Hamel, C., Gan, Y., and Vujanovic, V. (2012). Bacterial endophytes mediate positive feedback effects of early legume termination times on the yield of subsequent durum wheat crops. Can J Microbiol 58, 1368-1377.

Yang, X., Kundariya, H., Xu, Y.-Z., Sandhu, A., Yu, J., Hutton, S.F., Zhang, M., and Mackenzie, S.A. (2015). MutS HOMOLOG1-derived epigenetic breeding potential in tomato. Plant Physiol 168, 222-232.

Yesodi, V., Izhar, S., Hauschner, H., Tabib, Y., and Firon, N. (1997). Homologous recombination invoking cox2 is responsible for a mutation in the CMS-specific mitochondrial locus of Petunia. Mol Gen Genet 255, 106-114.

Zhang, D., Gardini, E.A., Motilal, L.A., Baligar, V., Bailey, B., Zuñiga-Cernades, L., Arevalo-Arevalo, C.E., and Meinhardt, L. (2011). Dissecting genetic structure in farmer selections of Theobroma cacao in the Peruvian Amazon: Implications for on farm conservation and rehabilitation. Trop Plant Biol 4, 106-116.

Zhou, X., and Platt, J.L. (2011). Molecular and cellular mechanisms of mammalian cell fusion. In Cell Fusion in Health and Disease, I. Cell Fusion in Health, T. Dittmar, and K.S. Zänker, eds., Advances in Experimental Medicine and Biology 713 (Dordrecht, Netherlands: Springer), pp. 33-64.

Zhou, X.M., Liu, Y.S., and Li, X.J. (2013). Confirmation of a purple-leaved plum graft hybrid. Genet Mol Res 12, 710-713. 


\section{Microbiology / Molecular Biology}

Caister Academic Press is a leading academic publisher of advanced texts in microbiology, molecular biology and medical research. Full details of all our publications at caister.com

- Cyanobacteria: Omics and Manipulation Edited by: DA Los (2017) www.caister.com/cyano3

- Brain-eating Amoebae: Biology and Pathogenesis of Naegleria fowleri

Author: R Siddiqui, IKM Ali, JR Cope, et al. (2016)

"explains the current knowledge and research" (ProtoView) www.caister.com/naegleria

- Foot and Mouth Disease Virus: Current Research and Emerging Trends

Edited by: F Sobrino, E Domingo (2017)

www.caister.com/fmdv

- Staphylococcus: Genetics and Physiology

Edited by: GA Somerville (2016)

www.caister.com/staph2

- Chloroplasts: Current Research and Future Trends Edited by: H Kirchhoff (2016)

www.caister.com/chloroplasts

- Microbial Biodegradation: From Omics to Function and Application

Edited by: J Długoński (2016)

www.caister.com/biodegradation

- Influenza: Current Research

Edited by: Q Wang, YJ Tao (2016)

www.caister.com/flu3

- MALDI-TOF Mass Spectrometry in Microbiology Edited by: M Kostrzewa, S Schubert (2016)

www.caister.com/malditof

- Aspergillus and Penicillium in the Post-genomic Era Edited by: RP Vries, IB Gelber, MR Andersen (2016)

"new and well-presented book" (IMA Fungus)

www.caister.com/aspergillus2

- The Bacteriocins: Current Knowledge and Future

Prospects

Edited by: RL Dorit, SM Roy, MA Riley (2016)

www.caister.com/bacteriocins

- Omics in Plant Disease Resistance

Edited by: V Bhadauria (2016)

"essential reading ... highly recommended" (Biotechnol. Agron.

Soc. Environ.)

www.caister.com/opdr

- Acidophiles: Life in Extremely Acidic Environments

Edited by: R Quatrini, DB Johnson (2016)

"Contributors from a wide range of biological and environmental sciences" (ProtoView)

www.caister.com/acidophiles
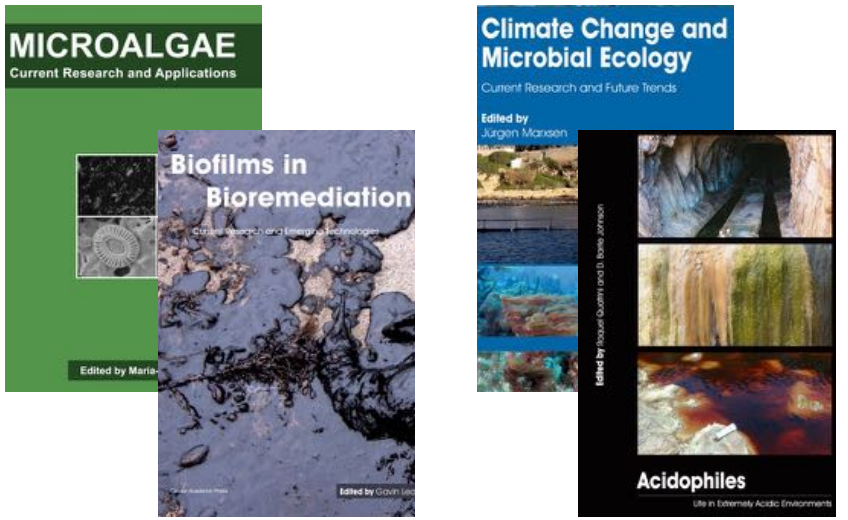
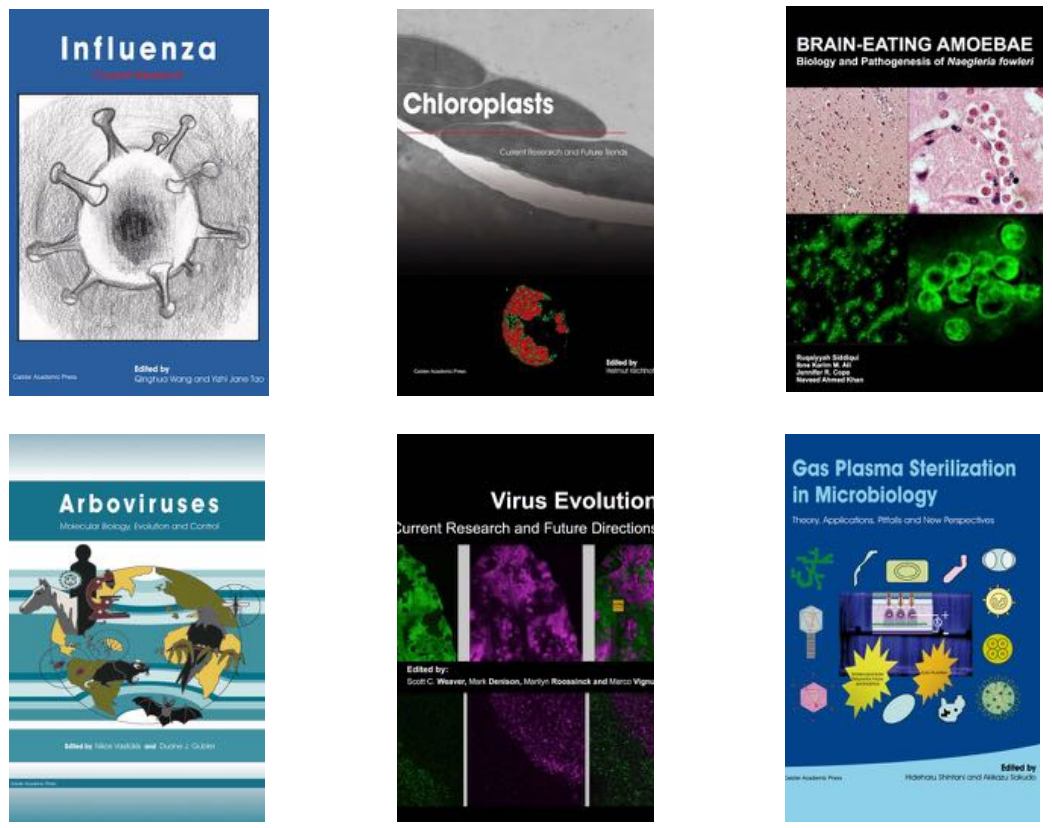

- Climate Change and Microbial Ecology: Current Research and Future Trends

Edited by: J Marxsen (2016)

"impressive" (ASM: Small Things Considered); "written at a high scientific level" (BioSpektrum)

www.caister.com/climate

- Biofilms in Bioremediation: Current Research and Emerging Technologies

Edited by: G Lear (2016)

"describes explicitly the role of biofilms in bioremediation" (Biospektrum); indispensable ... recommended (Biotechnol. Agron. Soc. Environ.) www.caister.com/biorem

- Microalgae: Current Research and Applications

Edited by: MN Tsaloglou (2016)

www.caister.com/microalgae

- Gas Plasma Sterilization in Microbiology: Theory, Applications, Pitfalls and New Perspectives

Edited by: H Shintani, A Sakudo (2016)

"a nice state of the art compilation" (Doodys)

www.caister.com/gasplasma

- Virus Evolution: Current Research and Future Directions Edited by: SC Weaver, M Denison, M Roossinck, et al. (2016) "highly informative ... a pleasure to read" (Microbiol. Today) www.caister.com/virusevol

- Arboviruses: Molecular Biology, Evolution and Control Edited by: N Vasilakis, DJ Gubler (2016)

"a thorough and compelling review ... an outstanding book ... highly recommended" (Am. J. Trop. Med. Hyg.) www.caister.com/arbo

- Shigella: Molecular and Cellular Biology

Edited by: WD Picking, WL Picking (2016)

www.caister.com/shigella

- Aquatic Biofilms: Ecology, Water Quality and Wastewater Treatment

Edited by: AM Romaní, H Guasch, MD Balaguer (2016)

"essential reference book" (Biotechnol. Agron. Soc. Environ.)

www.caister.com/aquaticbiofilms

- Alphaviruses: Current Biology

Edited by: S Mahalingam, L Herrero, B Herring (2016)

"up-to-date review of the field" (Aus. Vet. J.)

www.caister.com/alpha 